This PDF is a selection from a published volume from the National Bureau of Economic Research

Volume Title: Capitalizing China

Volume Author/Editor: Joseph P. H. Fan and Randall Morck, editors

Volume Publisher: University of Chicago Press

Volume ISBN: 0-226-23724-9; 978-0-226-23724-4 (cloth)

Volume URL: http://www.nber.org/books/morc10-1

Conference Date: December 15-16, 2009

Publication Date: November 2012

Chapter Title: Institutions and Information Environment of Chinese Listed Firms

Chapter Author(s): Joseph D. Piotroski, T. J. Wong

Chapter URL: http://www.nber.org/chapters/c12076

Chapter pages in book: (p. $201-242)$ 


\title{
Institutions and Information Environment of Chinese Listed Firms
}

\author{
Joseph D. Piotroski and T. J. Wong
}

The objective of this chapter is to describe the financial reporting practices and information environment of Chinese listed firms, to document the influence that local and national institutions have on reporting incentives and the resultant information environment in China, and to discuss how actual and potential changes in China's institutional and regulatory environment are expected to impact the country's information environment.

Following the framework outlined in Bushman, Piotroski, and Smith (2004), we define corporate transparency as the widespread availability of firm-specific information to those market participants outside the publiclytraded firm. At the country-level, we recognize that corporate transparency is the output of a multifaceted system whose components collectively produce, gather, validate, and disseminate information to market participants outside the firm. This output is generated by country, regional, and firmlevel information mechanisms that fall under three broad headings: (1) the corporate reporting regime, which includes the quality of the firm's financial reports and the underlying audit function; (2) the intensity of private information acquisition activities, which includes the depth and breadth of

Joseph D. Piotroski is associate professor of accounting at the Graduate School of Business, Stanford University. T. J. Wong is dean of CUHK Business School and a professor of accountancy at the Chinese University of Hong Kong.

This chapter has benefited from the comments of Joseph Fan and Randall Morck (editors), Li Jin (discussant), Bernard Yeung, and participants at the NBER "Capitalizing China" conference held at the Chinese University of Hong Kong in December 2009. Professor Piotroski acknowledges the financial support of Stanford University's Graduate School of Business. Professor Piotroski was the John A. Gunn and Cynthia Fry Gunn Faculty Scholar for 2010 2011. Professor Wong acknowledges the support of the Institute of Economics and Finance and the Center for Institutions and Governance of the Chinese University of Hong Kong. For acknowledgments, sources of research support, and disclosure of the authors' material financial relationships, if any, please see http://www.nber.org/chapters/c12076.ack. 
analyst and institutional investor activity; and (3) the strength of dissemination mechanisms, including the role of media and freedom of the press. This framework allows us to systematically document China's information environment and forms the basis for assessing the expected informational consequences of various institutional and market reforms in China. Given our background as accountants, specific attention is paid to the impact of the financial reporting system and audit function on the information environment in China.

It is well-established that the widespread availability of information is a key determinant of the efficiency of resource allocation decisions and growth in an economy. For example, at the heart of most theories about financial development is the key role that financial markets play in the reduction of information and transaction costs in an economy. Similarly, greater transparency and stricter disclosure standards have the capability of strengthening corporate governance by improving monitoring and limiting the consumption of private benefits by controlling shareholders, resulting in better asset management and investment decisions (e.g., Rajan and Zingales 2003; Stulz 1999; Doidge 2004; Doidge, Karolyi, and Stulz 2004). Consistent with these arguments, countries with strong information environments have been shown to garner significant benefits in terms of greater economic development, lower costs of capital, better functioning capital markets, greater foreign investor interest, and higher valuations. As such, greater corporate transparency has the potential to help developing economies such as China.

In spite of the developmental benefits arising from transparency, financial reporting practices and the resultant information environment are not exogenously determined; instead, reporting practices are the outcome of competing incentives for and against transparency. Given the concentrated ownership structures, weak legal systems, highly politicized institutional arrangements, rent-seeking behavior, and corruption that characterize many developing economies, the benefits from opacity frequently outweigh the market and contracting-based benefits of transparency. As a result, many emerging economies, including China, suffer from opaque information environments and weak corporate transparency.

In the case of China, great strides have been taken in the last decade in an attempt to improve corporate governance, accountability and transparency at both the state and firm level. Regulations mandating convergence toward IFRS (International Financial Reporting Standards), the use of IAAS (International Auditing and Assurance Standards), the presence of independent directors and limits on insider trading activity, along with broad government disclosure reforms and significant anticorruption programs, have been implemented with the goal of improving the investing environment in China. Yet despite these recent institutional and regulatory improvements, China's financial markets continue to be plagued by weak information systems and, as a result, low-quality financial information. 
The objective of this chapter is to provide a deeper understanding of China's information environment and the impact that the underlying institutional structure has on the financial reporting practices and information environment of publicly listed firms in China. Section 4.1 provides an overview of the information environment in China vis-à-vis other developed and developing economies. Section 4.2 describes the influence of China's legal, political, financial, and regulatory institutions on financial reporting incentives and the resultant information environment. Section 4.3 describes the state of information acquisition and dissemination activities in China. Section 4.4 concludes by outlining the expected impact of current and future institutional changes on the information environment of China's listed firms.

\subsection{Information Environment of China's Listed Firms}

The suppression of bad news remains an unedifying habit that dies hard on the Mainland.

—South China Morning Post, June 2007

Even in a China that is more capitalist than ever, the instinctive official response to bad news is to suppress it with all the force available to the nominally communist state.

—Financial Times, July 2007

Local politicians suppressed a company report about tainted milk powder until the completion of the Olympic Games to avoid "creating a negative influence on society."

—The People's Daily, October 2008

The influence of the State and politicians on China's information environment is a well-documented, publicized, and vigorously discussed topic both within and outside China. Although much has changed since the start of Deng Xiaopeng's economic reforms and his famous "southern excursion," information remains a powerful tool in the hands of China's local politicians and leaders. Currently, cultural and political incentives exist in China that prevents the widespread dissemination of unbiased information in a timely basis. The incentives for opacity span across a wide range of settings and topics, from environmental and health issues (e.g., tainted milk scandal, SARS and Bird Flu outbreaks) to government policy and actions (e.g., events of June 4, 1989) to demographic and economic data (e.g., growth data during the Asian Financial Crisis).

Given the rapid growth and increasing importance of China's capital markets, the natural question is whether the incentives for opacity extend to the financial markets and affect the reporting practices of Chinese listed firms. Investors, especially foreign investors, have a demand for timely, unbiased financial information to assess the risks, payoffs, and value of listed entities 
and other investment opportunities in the country. The demand for transparency also arises for stewardship purposes; credible financial reporting facilitates monitoring by both controlling and minority shareholders and allows for more efficient contracting arrangements, potentially resulting in better corporate governance practices and improved decision making at the firm level. Reporting firms have an incentive to supply this information to reap these benefits and to minimize the adverse pricing and resource allocation consequences arising from information asymmetry and illiquidity.

Despite these market-based and contracting-based incentives for transparency, there exist countervailing political, legal, and cultural incentives for opacity in China. Factors shaping these incentives include the desire to minimize political costs associated with the reporting bad outcomes, the need to hide expropriation and/or rent-seeking behavior, the importance of relationship-based contracting and social connections, and the effects of institutional arrangements that attenuate demand for information and high-quality audits (e.g., weak protection of property rights, concentrated ownership, limited contracting role for accounting). As a result of these countervailing pressures, China's capital markets are frequently ranked as one of the least transparent of the world's large economies.

The following sections present descriptive evidence on the quality of the information environment of Chinese listed firms using survey data and cross-country empirical evidence on the behavior of stock prices and financial reporting practices.

\subsubsection{Standards and Regulations}

On the basis of regulations and standards alone, the information environment for China's listed firms should be strong. As noted in the China Securities Regulatory Commission's (CRSC) 2008 annual report, one of the primary objectives of the commission is to "give priority to protecting the legitimate rights and interests of investors ... and maintaining the principles of an 'open, fair and just' market." At the heart of these objectives is a need for greater corporate transparency to increase the ability of investors, stakeholders, and the State to monitor the activities of listed firms. To that end, the CSRC has adopted US and European-style regulations and standards that promote transparency and strong corporate governance practices.

In terms of disclosure requirements, current CSRC regulations and the exchange rules of the Shanghai and Shenzhen Stock Exchanges require all listed Chinese firms to make periodic disclosures of the company's business activities and financial performance. ${ }^{1}$ These rules and regulations require all listed firms to provide an "annual report" within four months of the end of

1. Disclosure rules for Chinese listed firms can be found in chapter 3, section 3 of the Securities Law of the People's Republic of China (as amended August 29, 2004) and chapter VI of the Rules Governing the Listing of Stocks on the Shanghai Stock Exchange. 
each fiscal year, an "interim report" within two months following the end of the first half of each fiscal year, and "quarterly reports" within one month following the end of the first three and nine months of a given fiscal year. All annual reports are required to be audited by a qualified CPA firm. Quarterly reports are exempt from an audit requirement, while interim reports require an audit if the company plans to distribute profits, transfer reserves into share capital, or use the reserve to offset losses in the next half of the fiscal year. For accountability purposes, the directors and senior officers of the company are required to sign their opinion of consent or dissent to each periodic report, and if the financial report of the listed company is issued a modified opinion, directors are required to provide a specific explanation and express a specific opinion on the matter to which the modified audit opinion relates.

In addition to these periodic reporting requirements, listed firms are also required to file "ad hoc" reports when a "major event" occurs that is not yet known to investors and may considerably affect the price at which the firm's securities are traded. All reports and announcements are required to be published in the media outlet(s) specified by the relevant department of the State, as well as filed with the relevant stock exchange and the CSRC. Finally, all reports and announcements are required to be "truthful, accurate and complete; they may not contain any falsehoods, misleading statements or major omissions." Together, these reporting requirements should produce timely and accurate disclosures about corporate activities, operating performance, and the firm's financial conditional.

The CSRC has also implemented a series of regulations specifically designed to improve the quality of financial reporting and auditing practices of publicly-traded Chinese firms. The most noteworthy action in this area was the harmonization of Chinese accounting standards with International Financial Reporting Standards (2006) and, ultimately, the issuance of regulations mandating that listed firms comply with IFRS (effective January 1, 2007). Additionally, the CSRC has recently implemented new auditing standards and stricter auditor guidelines (effective January 1, 2007); these new rules follow the earlier adoption of International Auditing Standards in 1994. Together, these regulatory actions have the potential to improve the quality of the published financial reports through the convergence of Chinese practices with high-quality, globally-accepted standards and practices.

Finally, outside the direct realm of financial reporting, the CSRC has issued regulations to improve corporate governance and to reduce the incentives for directors and managers to withhold information from capital market participants. These regulations include stricter requirements for independent board membership, limitations on insider trading activity, penalties for activities that manipulate stock markets, and greater personal liability for the managers, supervisors, and directors of the listed firm for losses arising from "falsehoods, misleading statements or major omissions." The 
Chinese government has also introduced numerous ordinances and reforms designed to promote greater transparency and accountability within government and to counter political corruption. These actions have the potential to improve the investing environment in China, and should have a spillover effect on the information environment of listed firms by removing, or at least attenuating, some of the institutional frictions and costs that impede firm-level disclosure practices and inhibit the information acquisition and dissemination activities of market participants.

Unfortunately, it is possible that these reporting standards and regulations simply amount to "window dressing," adopted to ameliorate the concerns of foreign and domestic investors without producing any meaningful change in the information environment or governance practices (e.g., Berkowitz, Pistor, and Richard 2003; Allen and Shen 2011). Absent a commensurate increase in enforcement activities, existing institutional arrangements and cultural factors have the potential to erode the efficacy of these standards and regulations in practice. Ultimately, any assessment of China's information environment should be evaluated on the basis of practices and outcomes, not standards and regulations alone. The following sections outline this evidence.

\subsubsection{Evidence from the Behavior of Stock Prices}

Through the price formation process, market prices aggregate all available information. The accuracy and efficiency of these prices is influenced by numerous factors, including the disclosure practices of the listed firms, the acquisition and processing activities of information intermediaries, the effectiveness of information dissemination mechanisms, and the expected costs and benefits of arbitrage. As such, the behavior of stock prices represents one means of assessing the information environment of Chinese listed companies.

In an efficient market, stock prices react instantaneously and completely to new information; firm-level residual returns display minimal crosssectional correlation, no serial correlation, and approximate a log normal distribution. In markets with a limited flow of firm-specific information or significant trading frictions, stock returns will not take on these characteristics. Specifically, a limited supply of firm-specific information is expected to produce firm-level stock returns that are highly synchronized with general market movements (e.g., Roll 1988; Morck, Yeung, and Yu 2000; Durnev et al. 2003), while the systematic suppression of bad news will produce a stock return distribution that is significantly left skewed and subject to a greater frequency of stock return crashes (Jin and Myers 2006; Chen, Hong, and Stein 2001). Finally, the presence of market frictions, the absence of arbitrageurs and the activities of noise traders can result in a delayed reaction to new information, yielding serial correlated returns and momentum effects (Jegadeesh and Titman 1993; Chan, Jegadeesh, and Lakonishok 1996). Stock prices on China's exchanges exhibit all of these characteristics. 
First, China's stock prices exhibit high levels of comovement. In their seminal study on stock return synchronicity, Morck, Yeung, and Yu (2000) measure the average comovement of weekly returns for securities traded on the local exchanges of forty countries during 1995. Measured as both (a) the fraction of security prices moving together in an average week and (b) as the average $R^{2}$ of firm-level regressions of firm-level returns on local and US market indices, stock return synchronicity is designed to inversely measure the amount of firm-specific information being impounded into firm-level stock prices (see Roll 1998). Essentially, the synchronization of stock returns in a given market are expected to increase (decrease) in the absence (presence) of new firm-specific information.

Morck, Young, and Yu (2000) find that, on average, 57.9 percent of US stock prices move together in a given week, and market returns can be explained for approximately 2.1 percent of variation in firm-level returns. These percentages are the lowest of all surveyed countries, consistent with strong information and regulatory environment that characterizes US markets. In contrast, Morck, Young, and Yu (2000) find that nearly 80 percent of Chinese stocks move together in an average week, and market returns explain approximately 45.3 percent of the variation in weekly firm-level returns. $^{2}$ These statistics highlight the significant differences that exist in both the information and regulatory environments of the mature US market versus the developing Chinese market.

More striking, however, is the behavior of stock prices in China relative to the complete sample of developed and developing countries. Out of forty countries examined, China ranked second in terms of stock return synchronicity using both measures. This compares very unfavorably to the fraction of comovement in weekly returns documented in other large economies (e.g., UK $=63.1$ percent; Germany $=61.1$ percent; Japan $=66.6$ percent), in other large emerging economies (e.g., Brazil $=64.7$ percent; India $=$ 69.5 percent), and in Hong Kong (67.8 percent). ${ }^{3}$ Similarly, over the longer period 1991 to 2000, Jin and Myers (2006) find that Chinese firms displayed the highest level of stock return synchronicity out of the forty countries included in their study. Together, the evidence suggests that one of the defining characteristics of the Chinese stock market - highly synchronized stock price movements - is likely an artifact of the country's weak information environment.

Second, current research suggests that Chinese stocks are more crash prone than the global average. As discussed in Chen, Hong, and Stein (2001), a failure to release negative information in a timely manner will ultimately

2. Gul, Kim, and Qiu (2010) find, over the period 1996 to 2003, that daily market and industry returns explain approximately 45.4 percent of the variation in daily firm-level returns. Moreover, as discussed in section 4.3 , the level of stock return synchronicity observed is a function of the firm's ownership structure and audit quality.

3. Of the countries included in the study, only Poland exhibited greater stock return synchronicity during the sample period (82.9 percent). 
produce a larger subsequent price reaction when the information reaches the market. Consistent with large stock price crashes being driven by previously suppressed news, Jin and Myers (2006) show that the skewness of negative returns is inversely related to the level of disclosure in an economy. Although Jin and Myers do not specifically examine Chinese data, Piotroski, Wong, and Zhang (2011) show that the negative skewness in daily excess returns in China is significantly greater than the global average documented in Jin and Myers (2006), consistent with the existence of local incentives to suppress the release of bad news. Thus, a second key attribute of China's stock markets - a heightened risk of large negative stock price crashes - can also relate to the country's weak information environment.

Third, stock prices in China exhibit strong momentum effects. Using data from the Shanghai Stock Exchange's domestic A share market, Kang, Liu, and Ni (2002) and Naughton, Truong, and Veeraraghavan (2008) document the profitability of momentum investment strategies over the periods 1993 to 2000 and 1995 to 2005 , respectively. The authors provide evidence that momentum returns arise from the delayed impounding of firm-specific information, and that these portfolio returns are robust to numerous alternative explanations (bid-ask bounce; nonsynchronous trading effects; size effect) and considerations for transaction costs. Subsequent work suggests that some of the documented momentum effects could also be the result of powerful, speculative investors manipulating stock prices through a socalled "pump and dump" strategy (He and Su 2009; Khwaja and Mian 2005). Additionally, momentum effects could reflect the correlated behavioral biases of unsophisticated investors; such an explanation is plausible because Chinese retail investors, who tend to be very sensitive to short-term sentiment effects, are the predominant noncontrolling shareholders in Chinese listed firms (e.g., Choi, Jin, and Yan 2010). Regardless of the cause, the presence of momentum patterns in Chinese price data highlights potential deficiencies in both the information environment and the price formation process for publicly listed firms in China.

Together, this market-based evidence highlights some of the weaknesses in China's information environment. The next two sections will provide descriptive and contextual evidence on the nature of these deficiencies.

\subsubsection{Survey Evidence}

Each year, numerous country reports and surveys are published that assess the various legal, financial, and political risks associated with investing in foreign (and especially emerging) markets. These reports include the World Bank's "Doing Business Guide," the Heritage Foundation's "Economic Freedom of the World" country reports, and Transparency International's "Corruption Perception Index." As a part of these assessments, the underlying surveys frequently evaluate the country's financial reporting regime, the openness of government about financial policies and budgets, 
the country's record of protecting investor rights and enforcing contracts, and other aspects of the institutional environment that can affect the supply of and demand for timely and unbiased information. As a principle destination for foreign investment, China tends to be prominently featured in these surveys.

In a seminal survey on global transparency, PricewaterhouseCoopers (2001) assessed five country-level factors that contribute to or diminish the transparency of capital markets and the country's overall economic environment: level of perceived corruption, the legal system, economic policy at the government level, accounting and reporting standards, and the regulatory regime. Out of the original thirty-five countries surveyed by PricewaterhouseCoopers $(\mathrm{PwC})$, China ranked last in overall transparency (an opacity score of 87 out of 100), and was ahead of only North Korea in terms of the transparency of its accounting and financial reporting standards (accounting opacity score of 86 out of 100).

Since the original PwC survey, the Opacity Index has been produced by both the Kurtzman Group (2004) and the Milken Institute (2006 and 2008). These later versions of the survey have been expanded to include a larger set of developing countries and remeasured to capture fundamental changes in these economies. These recent surveys document two important facts about overall transparency in China. First, there has been a gradual improvement in the overall information environment over time; the Opacity Index fell from a score of 50 to 42 (out of 100) over the period 2004 to 2009. This improvement is principally driven by the aforementioned improvements to China's regulatory and legal environment and the implementation of specific exchange-level reporting and auditing requirements. Second, despite the improvement in China's overall score, the country continues to rank as one of the least transparent economies surveyed, ranking thirty-eighth (tied) out of forty-eight countries in the 2009 survey.

Focusing strictly on accounting and financial reporting transparency, similar conclusions are reached by these surveys (see table 4.1). First, China has experienced a significant relative improvement in its opacity score for "accounting and financial disclosure," improving from 56 to 40 (out of 100) over the period 2004 to 2009. This improvement mimics the general global trend toward transparency over the last decade. Second, despite this improvement on an absolute basis, China's accounting opacity score of forty continues to be the fourth-worst among the forty-eight countries surveyed in 2008; only Colombia, Saudi Arabia, and Nigeria fare worse. By contrast, other large emerging economies received accounting opacity scores of 26 (Russia), 29 (India), and 36 (Brazil), while China's Special Administrative Region of Hong Kong received an opacity score of 1.

Other reports offer similar conclusions about the opacity of China's financial reporting environment. For example, the World Economic Forum's Global Competitiveness Report (2011) specifically assessed the strength of 
Table 4.1

Descriptive statistics on China's accounting, audit, and disclosure standards: Survey evidence

\begin{tabular}{|c|c|c|c|c|c|c|}
\hline & \multicolumn{4}{|c|}{ Opacity index (score) ${ }^{\mathrm{a}}$} & \multicolumn{2}{|c|}{$\begin{array}{c}\text { Global } \\
\text { competitiveness } \\
\text { report (ranking) }\end{array}$} \\
\hline & 2001 & 2004 & 2008 & 2009 & 2008 & 2011 \\
\hline China & 86 & 56 & 41 & 40 & 86 & 61 \\
\hline United States & 25 & 20 & 20 & 20 & 20 & 40 \\
\hline United Kingdom & 45 & 33 & 10 & 11 & 17 & 15 \\
\hline Germany & - & 17 & 10 & 10 & 14 & 36 \\
\hline Japan & 81 & 22 & 21 & 21 & 44 & 35 \\
\hline Brazil & 63 & 40 & 37 & 36 & 60 & 49 \\
\hline India & 79 & 30 & 29 & 29 & 30 & 51 \\
\hline Russia & 81 & 40 & 26 & 26 & 108 & 120 \\
\hline Hong Kong & 53 & 33 & 1 & 1 & 1 & 12 \\
\hline Malaysia & - & 30 & 29 & 30 & 33 & 25 \\
\hline Singapore & 38 & 50 & 14 & 14 & 7 & 3 \\
\hline South Korea & 90 & 30 & 30 & 30 & 36 & 96 \\
\hline Taiwan & 56 & 40 & 30 & 30 & 53 & 30 \\
\hline Thailand & 78 & 20 & 21 & 21 & 58 & 56 \\
\hline
\end{tabular}

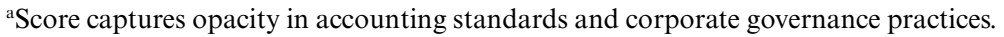

${ }^{b}$ Ranking captures the strength of auditing and reporting standards in the country.

auditing and financial disclosures in 142 countries. Similar to the conclusions drawn from the Opacity Index, China ranked sixty-first out of the 134 countries surveyed in the 2011 report, well below the rankings of key developed economies. By contrast, the other large developing economies were ranked fifty-first (India), forty-ninth (Brazil), and one hundred twentieth (Russian Federation), while local Asian economies Malaysia, Taiwan, and Hong Kong were ranked twenty-fifth, third, and twelfth, respectively.

Together, these surveys identify three important characteristics about China's information environment. First, overall transparency in China has been improving over the last decade in response to better regulation, stronger enforcement actions, and increasing demand from foreign investors. Second, despite these improving trends, overall transparency in China continues to lag at the levels observed in developed economies, such as the United States, United Kingdom, and Japan, the world's largest developing economies, especially India and Brazil, regional economies, such as Singapore, Taiwan, and Malaysia, and China's own SAR of Hong Kong. Lastly, these overall trends and rankings also apply to the financial reporting environment of China's listed firms, thus providing evidence on one dimension of corporate transparency that is likely contributing to the highly synchronized, crash prone, and serially correlated stock price behavior documented in prior research. 


\subsubsection{Financial Reporting Practices}

The preceding survey and returns-based evidence highlights the weak information environment surrounding China's listed firms. At the heart of the weak information environment are deficiencies with respect to the financial reporting and audit practices of China's listed firms. As outlined in section 4.1.1, the reporting requirements of Chinese listed firms mimic those used in most Western markets, and are designed to increase the supply of high-quality financial reports to market participants. Similarly, over the last two decades, market development and deregulation activities have increased the external demand for information about Chinese securities. Yet, despite these regulatory and market changes, the aforementioned surveys continually rank the quality of China's financial reporting practices as low relative to peer countries. These reporting deficiencies, and the adverse reporting incentives surrounding many of China's listed firms, have been illustrated recently by a string of high-profile accounting frauds committed by firms listed on foreign stock exchanges (e.g., Longtop, Media Express, Shangda Tech, Sino-Forest), and by the response of several key market participants to these scandals (e.g., research reports written by Moody's and Fitch). The natural questions are: how do financial reporting and accounting practices in China differ from the rest of the world? And, given that these differences exist, what local institutional factors create this disparity?

Unfortunately, to answer these questions, few studies directly compares the actual financial reporting and disclosure practices of Chinese firms against the reporting practices of other countries within the same study. For example, Bhattacharya, Daouk and Welker's (2003) examination of the link between accounting opacity and cost of capital, Leuz, Nanda and Wysocki's (2003) study of earnings management around the world and Bushman, Piotroski and Smith's (2004) study of corporate transparency around world and Fan and Wong's (2002) examination of earnings informativeness in east Asian countries all include Hong Kong firms in their respective samples, but do not include PRC-listed firms. Similarly, earlier seminal studies on the informativeness of earnings (e.g., Alford et al. 1993) and the properties of accounting numbers around the world (e.g., Ball, Kothari, and Robin 2000) only focus on large, developed economies. ${ }^{4}$

Despite these data limitations, there exists some key evidence on the overall quality of accounting practices in China. The most striking observation about the reported earnings of Chinese firms is the clustering of firm-level ROE realizations around 0, 6, and 10 percent annually (see figure 4.1, panel A). Because the CSRC uses bright-line regulatory benchmarks to

4. One constraint is that numerous cross-country studies exclude communist and formercommunist countries from their research design. Additionally, early cross-country studies of corporate reporting and accounting practices excluded China from their databases because of limited data availability during the early 1990s. 
A

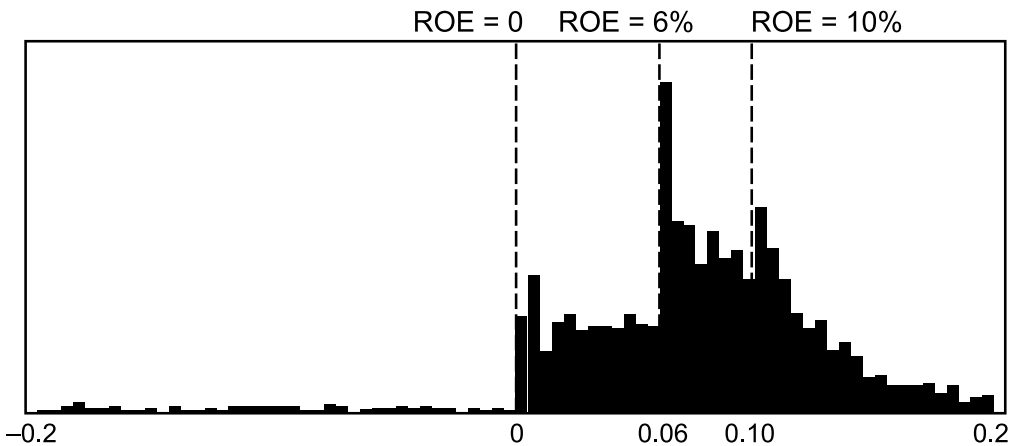

B

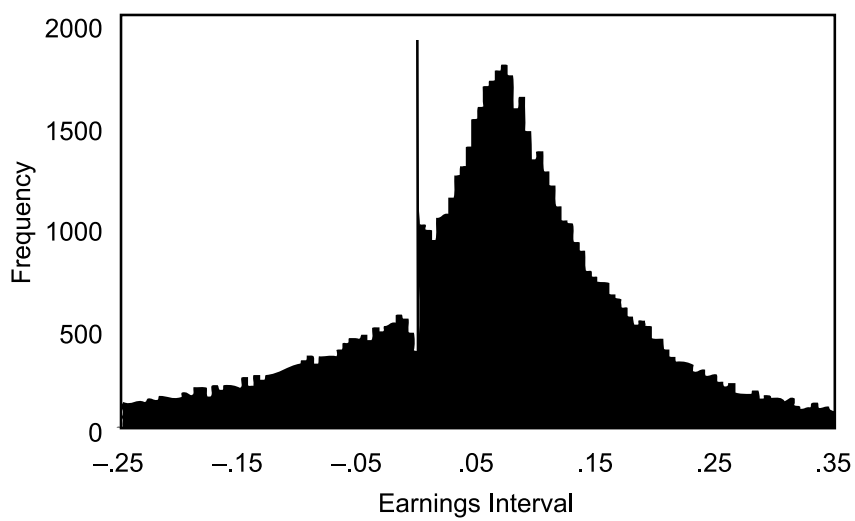

Fig. 4.1 Panel $A$ : Distribution of return on equity realizations of Chinese listed firms, histogram of ROE for China's listed companies from 1999 to 2001; panel $B$ : Distribution of return on equity realizations for US listed firms

Sources: Liu (2006); Burgstahler and Dichev (1997).

Notes: The distribution of annual net income (Compustat item \# 172) scaled by beginning of the year market value (Compustat item \# $25 \times$ Compustat item \# 199). The distribution interval widths are 0.005 and the location of zero on the horizontal axis is marked by the dashed line. When the interval width is 0.005 , the first interval to the right of zero contains all observations in the interval $[0.000,0.005)$, the second interval contains $[0.005,0.010)$, and so on. "Frequency" is the number of observations in a given earnings interval.

grant approvals for IPOs and rights offerings and to initiate performancerelated delistings, listed Chinese firms have an incentive to manage reported earnings to meet these specific performance benchmarks. As a result, a disproportionate number of Chinese firms report ROE realizations around the CSRC's historical performance benchmarks of 0,6 , and 10 percent. Moreover, there is almost a complete absence of loss-making firms in China. These distributional characteristics are especially striking when compared against a similar distribution of earnings realizations for US listed firms that do not face bright-line regulatory benchmarks (figure 4.1, panel B). Specifically, reported accounting realizations in China are influenced by the CSRC 
regulatory benchmarks, as evidenced by the concentration of ROE realizations at or above the prescribed regulatory cut-offs; in contrast, capital market pressures to avoid losses appear to be shaping the reporting behavior of US firms, as evidenced by the kink in earnings realizations around zero (e.g., Burgstahler and Dichev 1997). The results are financial statements that frequently do not reflect the real economic condition of listed Chinese firms, especially with respect to key capital market actions.

To achieve specific ROE targets and avoid losses, Chinese firms engage in both accruals-based earnings management and real transactions specifically designed to prop the performance of the listed firms. First, with respect to the use of discretionary accruals, Chen and Yuan (2004) document the booking of excessive non-operating income to meet the ROE requirements for a rights offering, while Aharony, Lee and Wong (2000) document the use of discretionary accruals to inflate earnings in advance of an IPO. Additionally, because the assets of listed state-controlled entities are carved out of local state asset management bureaus, they seldom have a stand-alone history prior to an IPO; as a result, these firms are allowed to report estimates of operating performance when applying for the initial offering, leaving the firm considerable latitude to meet earnings performance benchmarks. Together, these papers, among others (e.g., Chen, Lee, and Li 2003; Kao, Wu, and Yang 2009; Yu, Du, and Sun 2006; Liu and Lu 2007) show that Chinese firms use discretion available in the accrual accounting process to manage reported earnings to meet bright-line performance targets.

More generally, Ball, Robin, and Wu (2001) and Bushman and Piotroski (2006) demonstrate that the loss recognition practices of Chinese firms are less timely than for firms domiciles in other countries, even after the introduction of international accounting standards among listed firms. The limited application of conditionally conservative accounting practices among Chinese firms is striking when compared against the extent of timely loss recognition among the firms domiciled in key developed economies (see figure 4.2) and in large and local developing economies (see figure 4.3). The basic conclusion from these studies is that the accounting numbers of Chinese firms fail to capture deterioration in firm performance in a timely manner, severely limiting the usefulness of these reports for contracting and monitoring purposes. This particular reporting bias is especially problematic among listed state-owned firms, where the timely recognition of economic losses into accounting earnings would enable investors to better monitor managers and majority shareholders in the presence of weak corporate governance and potentially inefficient investment and asset management behavior.

Second, Chinese firms use related party transactions to meet earnings targets and avoid losses. For example, Jian and Wong (2010) document the prevalence of propping activities through related party transactions among China's state-controlled firms to manipulate the firm's earnings. Although the form of these transactions are real (e.g., product sales, raw material 


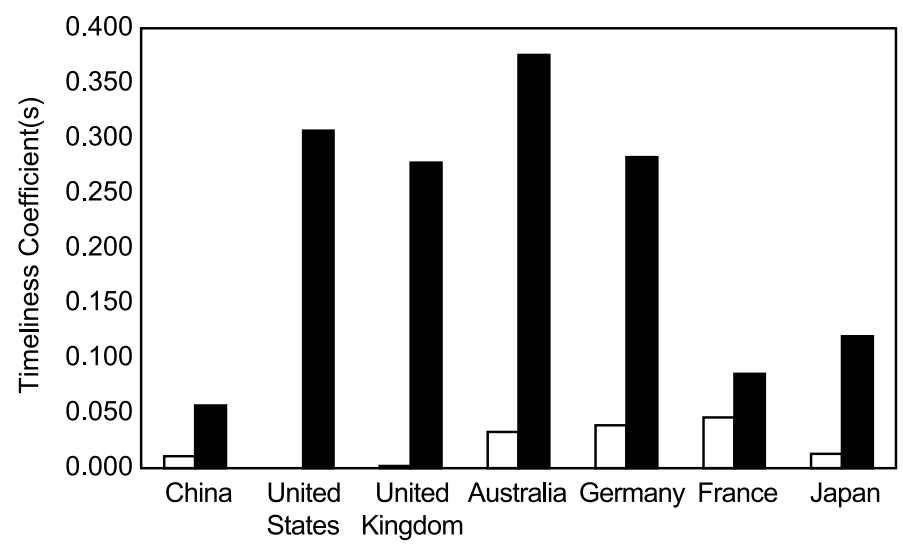

$\square$ Good News $\square$ Bad News

Fig. 4.2 Timely loss recognition practices of Chinese firms versus developed economies

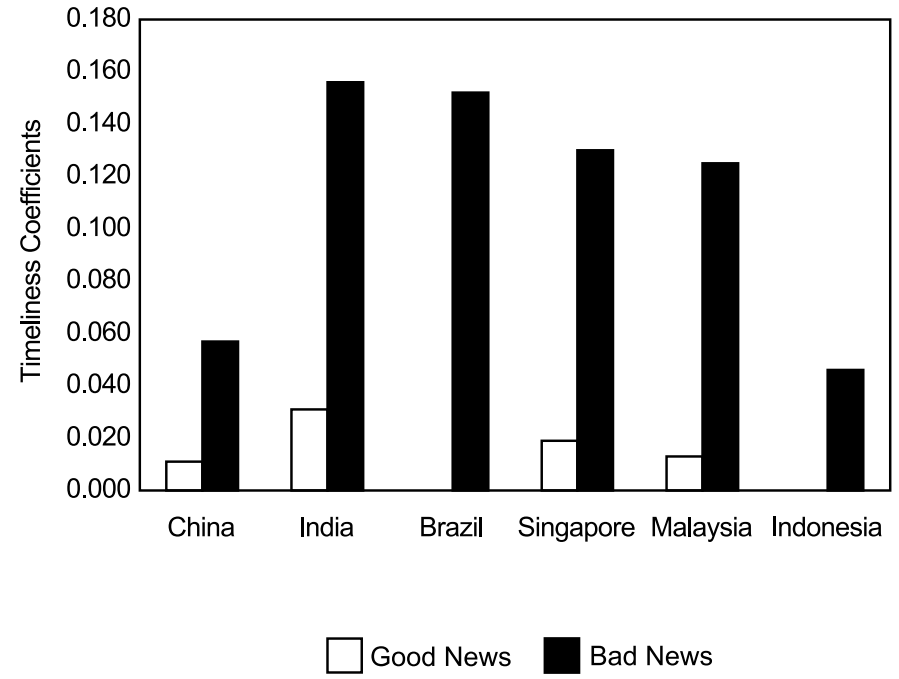

Fig. 4.3 Timely loss recognition practices of Chinese firms versus other emerging economies

purchases, intercompany loans, etc.), the substance of the transactions are designed to facilitate earnings management and, in many cases, tunneling activities. Moreover, Jian and Wong (2010) find that these earnings management effects were most pronounced in those provinces characterized by weak legal institutions and less deregulation of the marketplace, where the 
likelihood of detection and resultant penalties are expected to be lowest. Similarly, Jiang, Lee, and Yue (2010) document the widespread use of intercompany loans to facilitate the tunneling of resources in state-controlled firms while simultaneously propping up the listed firm's balance sheets.

Together, these papers illustrate alternative mechanisms by which China's publicly traded entities manipulate their reported performance to either meet the aforementioned regulatory requirements, to overstate the value of the firm to potential shareholders, to facilitate the tunneling of resources out of the publicly-listed firm and to hide poor outcomes arising from weak corporate governance. Thus, in spite of recent regulatory actions designed to foster transparency, the financial reporting environment of Chinese listed firms remains opaque. The discrepancy between the strength of China's standards and regulations and the relative weakness of China's actual financial reporting environment is ultimately the result of local institutions and arrangements that create adverse financial reporting incentives. The next section explores in greater detail the impact that China's unique institutional environment has on the financial reporting practices of its publicly listed firms.

\subsection{Institutions and China's Information Environment}

It is well documented that legal, political, financial, regulatory and cultural institutions exert strong pressures on economic agents and their behavior. In finance and economics, an extensive literature discusses and documents how primitive institutions influence the form of the economy, and the resultant impact the equilibrium set of institutions have on investor protections, financial development, investment behavior, economic growth and wealth. As a key institutional feature that aids in the allocation of capital within an economy, financial reporting practices, and the resultant information environment, are also shaped by these same primitive institutional forces.

In general, institutions associated with stronger investor protections and better economic outcomes are also associated with more favorable financial reporting practices and better information environments. For example, corporate transparency is greater in countries with stronger legal protections and minimal levels of state involvement in the economy (Bushman, Piotroski, and Smith 2004), earnings management is found to be less prevalent in economies with greater investor protection of minority shareholders and less concentrated ownership (Leuz, Nanda, and Wysocki 2003), timely loss recognition practices are stronger in countries with greater investor protections and institutions supporting contract usage (Ball, Kothari, and Robin 2000; Ball, Robin, and Wu 2003; Bushman and Piotroski 2006), earnings informativeness is higher in the presence of less concentrated ownership (Fan and Wong 2002) and stronger investor protections (DeFond, Hung, 
and Trezevant 2007), and the use of a high-quality auditor is more likely in the presence of strong institutions (Francis, Khurana, and Pereira 2003).

Unfortunately, many developing economies lack the institutional arrangements that create incentives for good governance, high-quality financial reporting practices, and transparent information environment. A weak legal infrastructure that fails to protect property rights will dampen the demand for high-quality accounting information for contracting purposes. These same weak legal institutions will also decrease the expected benefits associated with costly private information acquisition activities and inhibit the trading activities of arbitrageurs.

Additionally, the state's ownership of economic assets and the presence of strong political forces can give rise to adverse financial reporting incentives. In highly political settings, opacity arises to minimize the risk of government expropriation of the firm's assets, to hide inefficiencies and corruption, or to hide the rent-seeking activities of politicians and political cronies. For example, Bushman, Piotroski, and Smith (2004) document that the presence of strong state ownership in the economy and a greater risk of State expropriation creates incentives for opaque reporting practices, Bushman and Piotroski (2006) document that greater state involvement in the economy deters the timely recognition of losses into earnings, and Leuz and Oberholzer-Gee (2007) and Chaney, Faccio, and Parsley (2008) show that politically-connected firms report earnings of lower quality than nonpolitically-connected firms. Additionally, Wang, Wong, and Xia (2008), Guedhami and Pittman (2006), Gul (2006), and Guedhami, Pittman, and Saffar (2009) examine the impact of political forces on the quality of information around privatization events, and find that corporate transparency and the use of a high-quality auditor after privatization is inversely related to the portion of the firm's control retained by the State (and positively related to the extent of foreign ownership in these firms). Given the important role that government entities and politicians have in China's economy, political forces have the potential to exert a significant impact on the information environment of China's listed firms.

The following sections discuss and provide evidence on how China's institutional environment shapes the demand for and supply of information among China's listed firms.

\subsubsection{Institutions Influencing the Supply and Demand for Information in China}

In the US environment, accounting plays an important contracting role in the governance of listed firms (Watts and Zimmerman 1986). The use of accounting numbers in firms' managerial and debt contracts creates a demand for disciplinary mechanisms, such as the appointment of audit committee and external auditors, to ensure the reporting of high-quality information to all contractual parties, including existing and potential investors 
in the capital markets (Watts 2006). The stronger the contracting demand for credible information, the higher the accounting quality must be to fulfill this monitoring role.

The contracting role of accounting is first discussed in Jensen and Meckling (1976), who posit that there exists a contractual cost between ownermanager and outside shareholders; this contracting cost is termed agency cost. Accounting is an integral part of the organizational architecture in reducing this contracting cost. In a typical US listed firm, ownership is not concentrated in the hands of an owner-manager or family; instead, ownership is highly diffuse. This diffuse ownership structure creates a serious agency problem because of the separation of ownership and control in the organization. Essentially, the diffuse investors have delegated the control of the firm to professional managers whose interests are not aligned with theirs. This misalignment of interests is less problematic when managers are also part owners of the firm, because their stake in the company creates an incentive to maximize shareholder value. As a result, Fama and Jensen (1983) argue that firms characterized by diffuse ownership have a much stronger need to set up a governance structure that reduces the agency conflicts between professional managers and owners than firms with concentration in ownership. Specifically, firms with diffuse ownership need to appoint independent board members that are given the decision control rights to monitor managers on behalf of the owners. One frequently used monitoring device is an arm's length contract that links the managerial compensation to the firm's accounting performance. In order to validate the credibility of the accounting information, the board also hires external auditors to examine the managers' accounting reports on behalf of the owners (see figure 4.4).

Debt contracts also create a demand for high-quality financial reports in the US environment. Because creditors in the United States (especially bond holders) typically lack board representation and do not have privileged access to firm information, creditors frequently employ debt covenants based on accounting information to monitor the firm. Essentially, these debt covenants are used to trigger the transfer of decision rights from shareholders to creditors in the event of a decline in the financial condition of the firm. The efficacy of these contractual arrangements hinge upon the presence of credible financial accounting information and a judicial system that will enforce the underlying contract. The US strong legal environment, with its strong private enforcement channels, when combined with the prevalent use of public debt, leads to a heightened demand for high-quality financial reports by debt contracting parties. Thus, both the form of the US credit markets and the form of US equity ownership arrangements creates a strong contracting-based demand for high-quality financial reports. Finally, these same strong legal arrangements, namely the presence of a strong US judicial system that enforces contractual rights and an investors ability to engage in private litigation to recover losses, not only supports accounting-based 


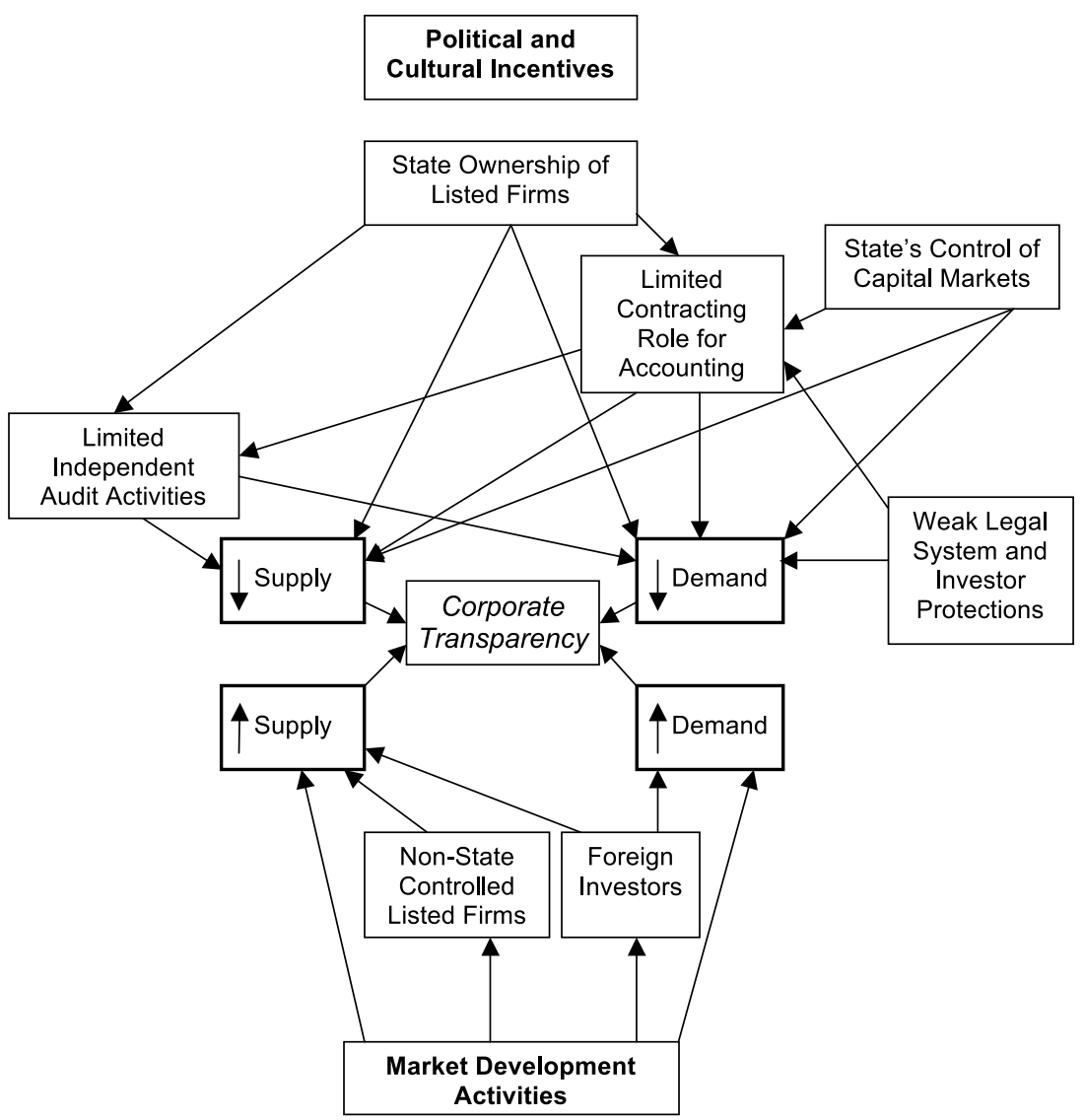

Fig. 4.4 Institutions and the supply and demand for information in China

contracting activity but also increases the benefits of engaging in costly information gathering, interpreting, and disseminating activities and creates a market-driven demand for information among US listed firms.

In contrast to the US environment, there exist a set of local institutional factors that shape the ownership, regulatory, and business environments of the Chinese listed firms. These institutions and related business arrangements, in turn, affect the contracting relationships of the key capital market players and, more specifically, the role and properties of externally reported accounting data for Chinese firms. These institutions and arrangements also influence the incentives of various capital market participants, and together, shape the demand and supply of high-quality financial reporting practices of publicly-listed firms in China. These key institutional arrangements include: State ownership of listed firms; government control of capital markets; weak market institutions and limited protection of property rights; lack of independent auditors; the importance of social networks and political 
connections. The impact of these institutional arrangements on the reporting practices of China's listed firms is discussed in the following.

\section{Majority of the Chinese Firms Remain State-Controlled after Listing}

China set up two stock exchanges in the early 1990s, one in Shenzhen and the other Shanghai, as a way to partially privatize its state enterprises and reform their governance structure to match international standards. However, the central or local government is required to maintain control of these state firms after listing. As of July 2010, the state owns on average 53 percent of the outstanding shares of listed state firms, while the remaining 47 percent of outstanding shares are in the hands of individuals, institutional investors, investment trusts and private firms. In addition, the government has historically given listing preference to state firms; as a result, state-controlled firms make up the majority of the equity market in the two stock exchanges (65 percent of firms with 89 percent of market capitalization).

Because of these ownership arrangements, the contracting role of accounting in a Chinese listed state firm is different from that of a US firm with diffuse ownership. First, concentrated control gives the State (i.e., majority owner) both the incentive and the ability to directly monitor the performance of the firms' managers. For example, the Chinese government retains the rights to appoint key officers such as the chairman and CEO of these state firms (Qian and Weingast 1997); as a result of this control, Fan, Wong, and Zhang (2007) document that 27 percent of the CEOs of listed state-controlled firms have government background. Moreover, as argued by Ball, Kothari, and Robin (2000), the government owners of listed state firms can use private channels and their political networks, instead of public accounting and information reported to the markets, to measure and assess managerial performance, thereby reducing the demand for high-quality external reports. As a result, the demand for high-quality external reports and information for control purposes is significantly lower among Chinese listed firms.

Second, bankruptcy is rare among listed state firms in China. As a consequence, most domestic investors expect the government to bail out state firms that are financially distressed. This implicit insurance against creditor and shareholder losses further reduces outside investors' demand for public information about the financial condition of listed state firms. Instead, investors focus on buying into firms that have strong political support.

Third, profit maximization is not the sole objective of most Chinese publicly-listed state-controlled firms; instead, these firms are also obligated to achieve certain social objectives, such as infrastructure development and full employment targets in the region. Because of these multiple and frequently conflicting objectives, local governments do not solely use firm-level profit information to monitor and assess the performance of the firms' managers. This reliance on other measures of performance reduces the demand for high-quality external financial reports. 
Lastly, because the controlling shareholder of a listed state-controlled entity is typically a state asset management bureau, or a holding company owned by the state bureau, listed firms are typically a member of a larger group structure. This structure introduces incentives that both limit the demand for information and suppress the incentive to supply information to the public markets. Specifically, transactions with related entities may rely less on arms-length contracts and, more generally, rely less on accountingbased contracts for enforcement purposes; instead, social norms and political costs are sufficient to compel each party to fulfill the terms of contracts, limiting the demand for credible, audited information from a strict contracting perspective. Moreover, this structure can facilitate propping and tunneling activities via related party transactions, creating an incentive to suppress information about group transactions in the presence of governance conflicts.

In summary, because of the state's controlling ownership in the vast majority of listed firms, the contracting role of accounting numbers in China is very different from that of US firms. This difference reduces the demand for high-quality external financial reports in China relative to the US market. Instead, a greater reliance is likely to be placed on internal reporting mechanisms and performance measures. Unlike their Western counterparts, very little is known about the information and control mechanisms used inside listed state-controlled entities. Future research in this area is warranted.

\section{Government Control of Capital Markets}

A unique feature of the Chinese environment is the State's strong control of the capital markets, especially as it pertains to state-controlled entities. Since the creation of the two stock markets in China, the listing process and subsequent share issuances are highly controlled by the CSRC. Furthermore, rather than leaving listing decisions to the market or the firm's managers, the government retains the ultimate power in selecting firms for IPOs and subsequent share offerings. Additionally, the central government has control over the credit market for most listed firms; this control arises because publicly-traded state firms typically obtain the majority of their debt financing from the four largest state banks in China.

The government's control of China's capital markets has two effects on firms' accounting practices. First, due to high information costs, the CSRC uses bright line rules to screen firms for rights offerings and delisting. For example, three consecutive years of losses will lead to delisting for Chinese firms, while return on equity realizations of 10 percent are required for a firm to engage in a rights issuance. ${ }^{5}$ And although the use of accounting-based

5. Effective July 2002, firms seeking a seasoned equity offering must have a three-year average return on equity (ROE) greater than or equal to 10 percent and have a ROE greater than or equal to 10 percent in the year directly preceding the offering. Similarly, firms seeking permission of a rights issuance must have a three-year average ROE greater than or equal to 6 percent. 
regulations appears to have been effective at screening out many unqualified listing candidates (see Chen and Wang 2007), without a strong market infrastructure to guard against manipulation, and with the CSRC's heavy reliance on these simple accounting targets to regulate the marketplace, listed firms have strong incentives to manage accounting realizations. These incentives result in firms using accounting discretion when measuring firm-level performance, as discussed previously in section 4.1.4.

Second, the Chinese government frequently turns to nonfinancial channels, such as political networks, to obtain information to make capital raising, financing, and listing decisions. For example, Fan, Rui, and Zhang (2008) document that politics influence the decisions of state banks to lend capital to state-owned enterprises, while $\mathrm{Du}$ (2011) documents the importance of political connections for firms to gain access to public debt markets. The extensive use of nonfinancial data for capital-raising transactions limits the demand for high-quality external reports in China.

Lastly, the prevalence of debt financing from state-controlled banks minimizes the need for external financial reports to fulfill a debt contracting role. Instead, the government owners of the bank can directly monitor and assess the financial condition of the state-controlled borrower.

\section{Weak Market Institutions and Limited Protection of Property Rights}

China was a planned economy prior to the reforms in the late 1970s. Despite the fast economic growth in the past thirty years, the government has retained control in many sectors of the market. For example, the government has the power to appoint key personnel in state firms, grant licenses for operations in a particular location, control and regulate the labor market and influence the supply of input materials and inventory. Thus, it is essential for all Chinese firms to develop and maintain good relations with the government. These political connections, when combined with China's weak legal system and a long tradition of relationship-based transactions in business, mean that the use of accounting numbers to enforce arms-length contracts is much less likely in this transitional economy; instead, these alternative political channels are used to seek enforcement and remedies for nonperformance.

More broadly, the current set of legal and financial institutions do not foster the activities of information intermediaries. First, because of the State's control over the markets and economy, Chinese investors are less likely to rely upon legal protections or information supplied by the firms or financial intermediaries when making their investment decisions. Instead, local investors focus on the firms' political background when choosing investment opportunities, and expect the government to bail but the firm if it experiences financial distress. As such, local investors do not create a demand for high-quality reports. Second, the evidence suggests that both institutional and retail investors in China have a short-term focus and tend to trade on the 
basis of broad macroeconomic factors and market sentiment; such trading preferences do not create a market demand for high-quality reports about individual firms. Lastly, the weak protection of investor and property rights, along with restrictions on foreign holdings and investment opportunities, limits foreign investment activity and the resultant demand for high-quality financial reports created by foreign investors.

\section{Independence of Local Auditors}

In the US environment, external auditors ensure that the managers accurately report the financial condition of the firm to outside investors. In that governance role, it is essential that the auditors represent the interests of the outside investors and remain independent of the managers; as such, the United States has instituted regulations designed to promote the independence of the audit function (e.g., the Sarbanes-Oxley Act). In China, however, the ownership structure of the state-controlled firms, combined with the market for audit activities, adversely affects the governance role of external auditors.

First, as controlling shareholder of a listed state firm, the government can directly communicate with and monitor its managers via internal channels; as such, the demand for external auditors to attest to the quality of public accounting reports is significantly lower in China. As such, the incentive to hire a high-quality external auditor is likely to be concentrated among non-state-controlled entities.

Second, prior to the reform in 1998, almost all the audit firms across China were state audit bureaus. Even today, these audit firms are supervised by their local government and retain many of their old political connections. For example, local finance bureaus, audit bureaus, and CPA institutes are in charge of the licensing of audit firms, the administration of qualifying examinations, and the regulation of audit firms' day-to-day operations (Zhong 1998; Tang 1999). These connections are likely to create conflicts of interest between the managers who are ex-bureaucrats and/or have strong political ties with the local governments and the auditors located in that same local region (local auditors). Moreover, this lack of independence can induce collusion between the local state firms and local auditors to expropriate minority shareholders, resulting in a reduced supply of high-quality financial reports.

\section{Social Networks and Political Connections}

As discussed in the preceding sections, social and political connections influence many dimensions of corporate activity in China; as such, any understanding of reporting incentives and China's information environment requires an understanding of the firm's political and social connections. For example, well-connected firms face a lower demand for high-quality external information, as contracts and other business arrangements rely heavily 
upon the personal reputation of each contracting party. Connected firms may also have an incentive to suppress financial information that either highlights the existence of these relations or casts unfavorable light on related party transactions designed to expropriate the firm's economic assets.

More generally, however, the reporting and disclosure practices of listed firms can be influenced by social and cultural norms that create a preference toward opacity. Corporate reporting activities, like all corporate activities, are executed by individuals whose behavior reflects not just a "value maximization" strategy, but the expected personal rewards and costs that would arise through compliance and noncompliance with social norms and customs. These compliance concerns certainly manifest themselves in the context of the political and social connections discussed previously, but really represent a more general cultural factor that influences corporate behavior in China. Future research is needed to better understand how social and cultural norms shape the incentives of China's executives and capital market participants, and the spillover effect these issues have on China's information environment.

\subsubsection{Recent Research on the Supply of and Demand for Information in China}

The preceding section outlines institutional arrangements that are expected to influence the reporting practices and information environment of China's listed firms. The following sections summarize recent research findings documenting the impact of these institutional arrangements on observed reporting practices and China's information environment.

\section{Politics and Suppression of Bad News}

One dimension of a strong corporate governance regime is the board's ability and willingness to take corrective actions when the firm experiences a deterioration in its performance. Additionally, the board is expected to be forthcoming with bad news to outside investors, whether through press releases, through communication with analysts, or from a financial reporting perspective, through the recognition of economic losses into earnings in a timely manner. In most common law countries, firms generally recognize economic losses into accounting earnings in a timelier manner than economic gains; this conditionally conservative accounting practice thus provides a mechanism that allows board members to closely monitor and discipline managers and to take corrective actions earlier. As discussed earlier, Chinese firms recognize losses into earnings in a less timely manner than firms domiciled in traditional common law countries (Ball, Robin, and $\mathrm{Wu}$ 2001; Bushman and Piotroski 2006).

So why are Chinese firms less likely to report bad outcomes in a timely manner? One explanation, put forth by Piotroski, Wong, and Zhang (2001), is that Chinese firms have strong political incentives to suppress bad news. 
On the demand side, the Chinese listed firms are under less pressure to report bad news promptly. As discussed earlier, the government ownership of the listed state firms and its control over the capital market weakens the contracting role of accounting, and thus the demand for timely reporting of bad news. On the supply side, the controlling owners of state firms also have political incentives to suppress bad news. Due to the heavy government control in the listed state firms, a large portion of politicians and ex-bureaucrats serve as senior executives and board members. They often pursue political goals or private benefit objectives at the expense of the firms' financial health. Thus, managers and local politicians incur a personal cost by reporting poor performance. Suppression of bad news allows politicians and politically astute managers to hide inefficiencies, expropriation-related activities, and mask the inefficient allocation of resources to achieve political objectives.

Using the crash statistics of share prices in Jin and Myers (2006) and Chen, Hong, and Stein (2001), Piotroski, Wong, and Zhang (2011) document that Chinese state firms control the release of bad news to the markets around three political events: the National Congress of the Chinese Communist Party, provincial-level promotions, and the revelation of provinciallevel corruption investigations. The promotion event involves turnover of local governors when they move to a more senior position. The measure of corruption events reflects the exposure of corruption cases involving provincial politicians at or above the bureau level. The results show that statecontrolled firms are significantly less likely to experience negative stock price crashes in the years of the National Congress of the Chinese Communist Party (CCP), in advance of political promotion decisions and during the course of corruption investigations relative to nonevent years. This suggests that in China, due to government's control over the capital markets and its ownership of the listed state firms, politics plays a significant role in shaping the information environment of these firms.

\section{Penalties for Accounting Scandals and Relationship-Based Contracting}

Another recent study by Hung, Wong, and Zhang (2011) uses penalties associated with accounting scandals to show that accounting has significantly less of a contracting role in China than the United States. In the US setting, Karpoff et al. (2004) and Karpoff, Lee, and Martin (2008a, 2008b) find that the reputation penalty to an accounting scandal is huge, with an average 41 percent decline in share prices for firms caught in accounting scandals sanctioned by the US Securities and Exchange Commission. They argue that a significant portion of the share price decline is associated with the loss in reputation, which leads to loss of potential new contracts or increase in future contracting costs. In contrast to the US experience, the reputational penalty against earnings management is significantly smaller 
in China. Hung, Wong, and Zhang (2011) find that accounting scandals sanctioned by the CSRC are associated with only about an 8.8 percent share price decline.

The major reasons for such a difference in reputational penalties associated with accounting scandals lie in China's institutional environment. With heavy government influence in the markets, and its weak development in market institutions and legal protection, Chinese firms tend to contract on the basis of social and political networks rather than public accounting information and legal documents; in contrast, US firms rely mainly on arm's length contracts. As such, accounting quality and corporate transparency are essential for various parties to enforce the firms' contracts in the US environment, and an accounting scandal damages the very credibility of the firm's underlying contracting environment. Chinese firms, on the other hand, focus more on their social and political networks in contracting; thus, an accounting scandal has minimal impact on the stability of the firm's underlying contractual relations.

In support of these arguments, Hung, Wong, and Zhang (2011) document that among firms with senior officers that were caught in corporate scandals that damage their ability to contract through political networks (e.g., bribing government officials or misappropriation of state assets), the share prices of these firms dropped by 30.8 percent, which was significantly more than those that were involved in accounting scandals. Because these corporate scandals will likely lead to a bigger disruption of political networks within the firms, they have a much bigger reputational effect on firms than accounting scandals. Hung, Wong, and Zhang (2011) also find that immediately after scandals that severed their political ties, these firms had a much harder time obtaining bank loans, and that there were significant changes in board membership due to changes in political appointees that helped to realign the firms' political networks.

\section{Earnings Management and Related Party Transactions}

A common way of measuring the information environment of a market is the level of earnings management among listed firms. Past research has found that Chinese firms have strong incentives to manage earnings. As discussed in the section on China's institutions, the government's bright-line rules for rights offering and delisting, and the weak reputational penalties and legal sanctions against accounting scandals, results in earnings management being prevalent among listed firms in China. There is extant evidence of earnings management in China, ranging from inflating earnings in years leading up to initial public offerings (IPOs) (Aharony, Lee, and Wong 2000), rights offering (Chen and Yuan 2004), and when facing ST (special treatment) status (Liu and $\mathrm{Lu}$ 2007).

Besides having strong incentives to manage earnings, the group structure 
of these listed Chinese firms also facilitates earnings management. Typically, a state firm will only carve out a portion of its assets for listing, leaving the rest in the unlisted parent firm. After the listing, the unlisted parent and the listed subsidiary often continue to trade with each other via related party transactions. The corporate structure of the group that the listed firm belongs to often has multiple layers and many firms in each layer. This complex structure is a result of diversification and vertical integration arising from the lack of developed input and output markets in China.

In a recent study, Jian and Wong (2010) document that the Chinese listed firms use related party sales to their unlisted parents to boost earnings to avoid delisting or qualify for rights offering. Similarly, preliminary research by the authors find that nonoperating related party transactions are associated with a decline in firm performance, while operating related party transactions improve firm performance. Moreover, among private, entrepreneurial firms, these nonoperating transactions increase the likelihood of the firm receiving a modified audit opinion and an enforcement action against it in future years, consistent with these transactions being used for suboptimal purposes. In contrast, state-controlled firms do not experience these adverse audit and regulatory outcomes, perhaps reflective of the benefits of being politically or socially connected.

This research raises a new set of questions on whether and how we should value listed firms in China, and the type of information that should be produced and released to evaluate these firms. For example, should listed companies be considered separate entities from their unlisted parent firms? Since almost all the parents of the listed firms are unlisted, it is difficult for investors to assess the true financial conditions of the listed firms in the market if the health and future performance of the listed company is inextricably linked to the health of the controlling firm or related entities. Should the reporting entity be expanded to include the parent company, or the group of firms controlled by the parent company? Whether and how do the ownership and governance structures affect the valuation of these listed firms in China? The influence of related party transactions, and the group and pyramidal ownership structure, represent several aspects of the information environment of Chinese listed firms that need further research and analysis.

\section{Weak Demand for External Auditing}

Prior US research shows that auditor quality can positively influence the information environment of client firms (e.g., Teoh and Wong 1993; Becker et al. 1998). As such, in a move designed to improve both auditing and accounting quality in the Chinese equity markets, the government adopted the international Generally Accepted Auditing Standards (GAAS) for the fiscal year of 1995. DeFond, Wong, and Li (2000) find that the immediate effect of such adoption is that the modified audit opinions go up by ninefold, from 1 percent to 9 percent. This significant increase suggests that Chinese 
auditors became more stringent when issuing opinions on the quality of their clients' financial statements following GAAS adoption. ${ }^{6}$ During this same time period, the Chinese government was attempting to develop a list of Top-10 auditors (based on number of clients or clients' total assets) with superior audit quality. Consistent with the government's desire, DeFond, Wong, and $\mathrm{Li}$ (2000) also find that everything else equal, these Top-10 auditors are indeed more stringent, issuing more modified opinions in a sample period of 1993 to 1996 . However, after the adoption of the new GAAS in 1995, the market share of Top-10 auditors drops significantly and has remained such for the last decade. ${ }^{7}$ So, the obvious question is: Why did the demand for Top-10, higher-quality auditors in China fall after the adoption of the new GAAS?

The reason for such a low concentration of Top-10 auditors again relates to China's institutional environment. As highlighted earlier, block ownership and the likelihood of a government bailout in times of financial distress reduces the demand for the governance role of external auditors. Additionally, the reliance on political networks rather than arm's length contracts further weakens the contracting role of accounting and the demand for high-quality external auditing. Thus, it is unnecessary for state firms to hire Top-10 auditors.

Wang, Wong, and Xia (2008) also propose an alternative explanation for their result that local state firms tend to hire non-Top-10 auditors from the same region (local auditors). Wang et al. (2008) argue that local governments retain substantial political influence over these small local auditors; by hiring local auditors, local state firms can collude with the auditors in managing earnings to meet government targets and/or suppressing bad news for political goals. Wang, Wong, and Xia (2008) report that compared with nonstate firms, local state firms are more likely to hire small local auditors. Moreover, the relative difference in the propensity to hire small local auditors is greater in provinces with more government influence and weaker legal institutions, consistent with political forces shaping the audit choice decision.

\subsection{Other Dimensions of Corporate Transparency in China: Information Intermediaries and the Media}

Financial reporting is at the heart of a listed firm's information environment; as a result, the preceding sections have focused on understanding financial reporting practices in China. However, other facets of corporate transparency, such as the intensity of information acquisition activities, the strength of the country's information dissemination mechanisms and, ulti-

6. Similar evidence on the issuance of qualified reports is found in Yang et al. (2001) for disaffiliated CPA firms in 1997.

7. Wang, Wong, and Xia (2008) document that only 25 percent of the listed firms in China hire Top-10 auditors in 2003. 
mately, the extent of informed trading activity, can have a significant impact on the development of a strong information environment. In China, many of these dimensions of corporate transparency are either lacking or not well understood.

Prior research documents a host of economic benefits arising from the presence of strong information intermediaries, such as financial analysts and institutional investors. These benefits range from the more efficient pricing of historical information, greater liquidity, and smaller bid-ask spreads. Additionally, the firm's disclosure practices themselves tend to be intertwined with the presence of information intermediaries; analysts and institutions tend to cover firms with better disclosure practices, and once a relationship is established, these information intermediaries exert pressure on management to supply more information (Gelos and Wei 2004). Thus, firms wishing to obtain the benefits arising from greater analyst coverage and institutional ownership are required to improve their disclosure practices to both attract and retain such coverage. ${ }^{8}$ This section will provide evidence on the informational activities of institutional investors, analysts, and the media in China.

\subsubsection{Institutional Investors}

As sophisticated investors, institutions can improve the efficiency of stock prices through their trades and arbitrage activities. As minority shareholders, institutional investors have the ability to monitor the firm's management and controlling shareholders and exert pressure on management to provide information in ways that neither domestic nor foreign individual investors can. As a result, institutional trading activity and institutional ownership arrangements have the potential to improve the information environment of China's listed firms.

However, weaknesses in China's legal and regulator institutions likely hinder the ability for foreign and domestic institutions from fulfilling these roles. For example, the weak protection of property rights, the limited ability to privately enforce contracts and concerns about corruption, cronyism, and market manipulation will limit expected gains from private information acquisition activities and crowd out informed trading activity. Regulatory and exchange-related frictions, such as restrictions on short selling activity, the existence of daily price movement limits, the lack of intra-day trading, and higher transaction costs hinder institutions from effectively engaging in certain arbitrage activities. ${ }^{9}$ Similarly, regulatory restrictions on foreign

8. Alternatively, it is possible that analysts and institutions prefer to follow firms with limited information, which offer the largest benefit to private information acquisition and trading activity. In such a setting, the informed trading activities of institutional investors would serve as a substitute for firm-level reporting and disclosure practices.

9. Current regulations limit the daily downside price movements of listed Chinese firms to minus 5 or 10 percent, resulting in market prices that do not fully reflect extreme negative 
ownership and the activities of foreign financial institutions reduce the institution's incentive to serve as long-term monitors and stakeholders of China's listed companies. Finally, the dominance of state-owned firms and their heavy reliance on social and political networks for contracting induce corporate opacity and restrict the role of financial intermediaries in gathering and disseminating value relevant information of these firms.

Empirical evidence on the information acquisition and dissemination activities of institutional investors and their effect on the price formation process is lacking in the context of China's securities markets. Research on the trading behavior of institutional investors in the Shanghai A share market finds that domestic institutions follow momentum/price feedback strategies; such trading behavior is consistent with institutional investors discounting their private information about fundamental valuations when making their portfolio allocation decisions, and instead trading on the basis of market sentiment, information contained in past trades, and general market movements (e.g., Mei, Scheinkman, and Xiong 2005; Tan et al. 2008; Kling and Gao 2008). If that interpretation is correct, this trade-based evidence suggests that the China's weak legal and regulatory environment hinders at least one informational role served by institutional investors. Future research is needed to determine whether, and to what extent, institutional frictions are limiting the arbitrage and information gathering activities of sophisticated domestic and foreign institutional investors in China. Alternatively, to the extent that both institutional and retail investors have a short-term focus and a preference for trading on market sentiment or macroeconomic indicators, it is possible that a greater supply of firm-specific information will result in only minimal changes to behavior of investors and security prices in the Chinese market. Future research examining the trading activity of institutions following the elimination of informational frictions is warranted.

Future research is also needed to understand the governance and monitoring role played by these institutions in the context of China's listed firms. For example, are domestic and foreign institutions (as minority shareholders) able to exert influence in the presence of state control? What if the controlling shareholder is an entrepreneur or family group? Has increased institutional ownership influenced corporate governance practices, disclosure practices, and firm performance? How has the gradual relaxation of restrictions on the activities of foreign institutional investors changed the supply and demand for firm, industry, and country-level information, and how have those changes affected the price formation process? Future research in this area is warranted.

information events in a timely manner. The sluggish response of prices to new information introduces a costly friction that can impede the activities of information arbitrageurs. Additionally, the lack of intra-day trading and transaction costs that are about 50 basis points higher than that of more mature markets also reduces the overall efficiency of the marketplace. China Capital Market Development Report (CSRC 2009) 


\subsubsection{Financial Analysts}

The preceding evidence on the behavior of institutional investors suggests that buy-side analysts are not fulfilling a key informational role in China. With respect to the activities of sell-side financial analysts, early research documents that analyst forecast errors for Chinese listed firms are nearly twice as large as those for Hong Kong listed companies, and significantly larger than those of other developed and developing Asia Pacific countries (e.g., Ang and Ma 1999). This pattern is consistent with domestic Chinese analysts grappling with limited information and/or having minimal incentives to gather and produce new information when making firm-level forecasts. Subsequent research focuses on examining analyst forecast accuracy conditional on whether or not foreign investors trade in the given security. These papers find that the relation between forecast accuracy and analyst coverage strengthens in the presence of foreign investor activity, suggesting that either the demands of foreign investors led to greater information production by analysts or that the presence of foreign investment promoted a greater supply of information by the firm. Regardless of the cause, the paper illustrates the type of dynamic interactions that can exist between the presence of foreign investors, changing market regulations, and the information environment of listed firms. Future research is needed to examine the role of politics, development of market and legal institutions, and how ownership structure of Chinese listed firms affect the supply and demand of analyst forecasts in China. Additionally, future studies should seek to understand the forecasting, reporting, and coverage incentives of both domestic and foreign financial analysts in China, the type of new information, if any, that they contribute to the price formation process, and how shifts in China's regulatory environment are changing the incentives of information intermediaries.

\subsubsection{Media and Other Information Dissemination Mechanisms}

Lastly, the information environment surrounding China's markets and listed firms is shaped by the strength of the country's information dissemination mechanisms. These mechanisms include the aforementioned activities of financial analysts, who through their various investment and industry reports disseminate firm-specific and industry-specific information to a wider set of market participants. More importantly, corporate transparency depends critically upon the role of the media and the Internet to disseminate firm-specific financial information to both domestic and foreign investors.

In this regard, several issues of note arise in China. First, the vast majority of media outlets in the PRC are owned by the State, and to the extent that political incentives prevail, the firm-specific information conveyed through these media outlets is likely to be biased and the supply of information constrained. Moreover, because a state license is required to operate a media outlet in China, the reporting incentives of non-state-owned media outlets 
are also likely to be influenced by the objectives of the State and local politicians. This lack of independence in reporting would be particularly serious if the news coverage is associated with SOEs that are controlled by the same local politicians. Future research is needed to understand the influence these political pressures have on media coverage and reporting bias in the financial press.

Second, the Internet is a rapidly expanding source for financial information globally. Listed firms post financial information on corporate websites, conference calls and presentations are streamed live and archived on the Web, and both formal and informal news outlets, including financial weblogs and websites, exist to gather and disseminate (and in some cases produce) value-relevant information about listed firms. These outlets often produce independent news coverage because quite a number of them are privately run and escape state censorship. Given the rising importance of the Internet for information dissemination, one must ask whether the "Great Firewall of China" extends into the realm of reporting and disseminating financial information? Recent events involving Google's decision to temporarily suspend operations in China over censorship concerns, for example, suggests that an implicit contract exists between Internet service and content providers and the Chinese government. Similarly, the recent enactment of a regulation that limits the ability of individuals to register domain names is an example of how the government can use regulation to control how information about China's listed firms is disseminated. Whether Internet outlets are important sources of unbiased corporate news to investors in China and whether new regulations will limit their role in generating corporate information are important questions for future research. Research on whether and how political factors influence the flow of firm-specific financial information through China's various media outlets and channels is needed.

\subsection{Evolution of China's Information Environment}

The preceding sections outline the current information environment in China and highlight the influence that local institutions have on financial reporting incentives. The final sections of this chapter discuss how actual and potential changes in China's institutional and regulatory environment are expected to impact the country's information environment, and the expected consequences associated with changes in corporate transparency.

\subsubsection{Potential Consequences from a Change in Corporate Transparency}

Prior research documents the potential economic benefits that can arise from strong corporate reporting and disclosure practices at both the firm and country level. The following paragraphs outline the expected consequences in the context of China.

First, prior research using US data shows that firms with better disclosure 
practices are associated with lower levels of information asymmetry and less uncertainty about future performance, as measured by smaller absolute analyst forecast errors and narrower dispersion of analyst forecasts. The reduction in information asymmetry and estimation risk translates into smaller bid-ask spreads, greater liquidity, and ultimately, lower costs of equity and debt capital (e.g., Barry and Brown 1985; Botosan 1997). Similar relations exist between the quality of reported earnings, information asymmetry, and the firm's cost of capital using both US data (e.g., Francis et al. 2004) and cross-country data (Bhattacharya, Daouk, and Welker 2003).

Additionally, US data shows that firms with more transparent disclosure practices are associated with greater levels of analyst coverage (Lang and Lundholm 1996). To the extent that greater analyst coverage improves overall information gathering, processing, and dissemination activities, the increase in analyst coverage should improve the efficiency of stock prices, reduce information asymmetry, lower trading costs and improve resource allocations. Furthermore, to the extent that greater analyst coverage is positively related to the overall level of investor interest in the firm, greater demand for the securities can increase liquidity, raise valuations, and lower the firm's cost of equity capital (Merton 1987).

Together, the evidence suggests that the credible adoption of transparent reporting and disclosure practices by Chinese firms has the capability of reducing market frictions arising from information asymmetry and adverse selection concerns, potentially lowering trading costs and increasing liquidity for the firm's shares. These shifts are expected to increase the efficiency of market prices and raise firm valuations in the long run. The evidence also suggests that listed Chinese firms could benefit from a reduction in their cost of capital.

The magnitude of this benefit for China's listed firms, however, is debatable. The magnitude and duration of any cost of capital benefit will ultimately depend upon the credibility of the firm's commitment for transparency, the extent that capital is actually being directly raised by the firm in a market setting, and the scarcity of external capital in China. The issue of credibility is straightforward; only a persistent shift in reporting practices has the potential to yield the benefits outlined previously. The suspension of recently enacted regulations or a lack of credible enforcement activities will result in unraveling of these benefits. As for capital raising activities, listed firms in China continue to raise the majority of their external funding from state banks or via politically-influenced channels. If this trend continues, the expected magnitude of the cost of capital benefits from increased transparency will be small or nonexistent. Finally, given the high savings rates in China, nominal costs of capital in China are already low. As a result, the expected cost of capital benefit from a reduction in information asymmetry and liquidity may be economically small in the short term.

Second, in the context of an emerging economy like China, where own- 
ership is concentrated in the hands of the state or a few nonstate owners, greater transparency and stricter disclosure standards have the potential to strengthen corporate governance by improving monitoring and limiting consumption of private benefits by controlling shareholders (e.g., Rajan and Zingales 2003; Stulz 1999; Doidge 2004; Doidge, Karolyi, and Stulz 2004). These governance improvements should result in better asset management and investment decisions for the firm and lower the risk of expropriation by the controlling shareholders. These improvements should produce stronger firm performance, lower costs of capital, higher market valuations, and from the perspective of minority shareholders, larger dividends and greater free cash flows. Consistent with these corporate governance arguments, Bushman, Piotroski, and Smith (2011) show that firms operating in economies with timely accounting loss recognition practices respond to a decrease in growth opportunities more strongly than firms operating in economies with limited loss recognition practices.

Third, strong information systems lower the information gathering costs investors, increase investor protections through the use of enforceable contracts, allow for improved monitoring, and lower the uncertainty faced by foreign investors. Consistent with these arguments, Gelos and Wei (2004) show (using cross-country data) that stronger disclosure practices are associated with greater levels of foreign investment, while Gul, Kim, and Qiu (2010) find that stock price synchronicity in China is inversely related to the level of foreign holdings. Thus, a change in corporate transparency is likely to produce a change in the investment activity of foreign investors. However, the magnitude of this effect is likely to depend upon the objectives of foreign investors; to the extent that foreign investors are purchasing Chinese securities as a means of capturing expected appreciation in the Chinese currency (vis-à-vis the US dollar), or are trading on the basis of macro-trends or investor sentiment, incremental changes in the information environment of listed firms may have only a marginal effect on the level of foreign investment and holdings.

Finally, all of these outcomes are expected to improve the price-setting process in China's markets, ultimately resulting in market prices that will better aid in the allocation of the country's capital toward the most promising investment opportunities. Combined with expected improvements in corporate governance practices, the resource allocation effects arising from greater corporate transparency are likely to produce the largest economic benefits for China over the long run.

In summary, a credible commitment for strong disclosure and financial reporting practices is expected to aid in China's economic development through greater levels of foreign investment and an improvement in the allocation of capital through the more accurate identification of positive net present value (NPV) investment projects and better asset management. Improvements in firm-level cost of capital are possible, but likely to be 
less important economically in the short term. As will be discussed in the next section, the growing number of nonstate firms and the gradual decrease in the dominance of SOEs in the market will increase both the supply of and demand for corporate transparency. Additionally, as greater amounts of foreign capital flow into the economy, foreign and minority shareholders will demand higher-quality information and audit function to monitor both managers and controlling shareholders, reinforcing the aforementioned benefits.

\subsubsection{Expected Impact of Current and Future Institutional Changes on Corporate Transparency and China's Information Environment}

China's economy has undergone an incredible transformation over the last several decades, including the introduction of public equity markets and the embracing of many Western-style market arrangements. This market development, along with the arrival of foreign capital, has created a demand for better information about China's listed firms. However, many attributes of the Chinese environment - the State's ownership of listed firms, concentrated ownership structures, a cultural preference for relationship-based transactions, and the role of political connections and incentives-have remained fairly unchanged over this same time period. It is these institutional attributes that have driven a wedge between the market demand for corporate transparency and the listed firm's willingness and need to supply that credible external information for valuation and contracting purposes.

The preceding evidence suggests that, in terms of economic and financial development, China would benefit from an improved information environment and stronger financial reporting systems. However, transparency is not costless. The aforementioned political, legal, and cultural factors create incentives for weak external information systems in China. If the government of China desires an improvement in corporate transparency, it will require a shift in these institutional arrangements. The following subsections discuss the expected impact that different institutional changes would have on the information environment of listed firms given the prevailing incentives for opacity.

\section{Adoption and Enforcement of Credible Accounting Standards and Regulation}

By adopting standards that converge with IFRS, China has benchmarked their accounting standards to global standards. The CSRC has stated in numerous documents and reports that transparency is an important objective for its markets. Given China's desire to improve the information environment of its publicly listed firms, the adoption of International Financial Reporting Standards, International Auditing Standards, and a host of other globally-recognized governance and reporting regulations represent a good first step toward achieving that objective. Unfortunately, internationally 
accepted accounting standards and regulations alone are not sufficient to improve the information environment; if transparency is desired, the information disclosed must be tailored to the business environment and there must exist credible mechanism to enforce these rules.

Due to the organization and incentive structure of Chinese listed firms, standard setters and regulators have begun to tailor the disclosures of listed firms to provide information about related party transactions and the complex pyramidal and ownership structure of these listed firms. Greater information about these types of transactions and arrangements should allow outside investors to better monitor the activities of the firm; such monitoring should improve corporate governance and allow for the production of more accurate market prices.

More importantly, managers, politicians, and firms will only have an incentive to follow these rules if the costs of noncompliance are sufficiently strong. Prior research shows that the enactment of laws and regulation are insufficient to derive economic benefits. For example, Bhattacharya and Daouk (2002) show that it is the initial enforcement of a country's insider trading law, not the law's enactment, which results in a decrease in countrylevel costs of capital. Similarly, Bushman, Piotroski, and Smith (2005) show that it is the initial enforcement, not enactment, of those same insider trading laws that results in an increase in the depth and breadth of analyst coverage in an economy. In this regard, a strong central regulator such as the CSRC is in the position to act as the public enforcer, similar to the Securities and Exchange Commission in the U.S. If China begins the process of credibly and impartially enforcing existing securities laws and regulations, then many of the impediments against corporate transparency should fall and the information environment of publicly listed firms will improve over time. ${ }^{10}$

\section{Legal System Reforms}

As China continues to reform its legal and judicial system to be free from political influence and corruption, we expect to see an improvement in corporate transparency in China over time. Prior research shows that strong legal systems create an institutional and market environment that promotes and creates a demand for strong financial reporting practices (e.g., Ball, Kothari, and Robin 2000; Leuz, Nanda, and Wysocki 2003; Bushman, Piotroski, and Smith 2004) and attracts foreign investment. These strong legal systems promote the private enforcement of contracts, produce decisions that are made in a fair and transparent manner, and operate independent of political policy objectives and local connections. A credible

10. Moreover, as noted in Allen, Qian, and Qian (2005), IAS-based standards may be counterproductive given current institutional arrangements. Particularly, the inherent discretion imbedded within IFRS, when combined with weak auditing practices and an ineffective judicial system, could actually result in weaker corporate reporting practices vis-à-vis the simpler set of Chinese accounting standards that IFRS is replacing. 
shift in China's legal regime will serve to strengthen investor protections in China, creating a climate for foreign investment, arm's-length contracting activities, and the resultant information gathering and auditing activities. Recent events in China, which include the adoption and enforcement of insider trading laws and the first prosecution of a civil servant under these laws, are consistent with credible regulatory and judicial reforms. However, local judicial courts are often under the strong influence of local politicians; this political influence makes enforcement of these new laws difficult. Absent the elimination of these political frictions, regulatory reforms alone will be insufficient to produce significant improvements in the information environment.

\section{Expansion of Market Demand for Information}

Regulations and laws (and related enforcement activity) that create market pressures for better corporate governance at the firm level and greater information gathering activities by outside investors are expected to strengthen China's information environment. One approach is the relaxation of rules on foreign investing and ownership in China. Historically, foreign investors have been limited to the B share market in China or the $\mathrm{H}$ share market in Hong Kong; however, recent changes in regulation have begun to allow greater holdings by foreign investors. In December 2002, China launched the Qualified Foreign Institutional Investor (QFII) program to allow licensed foreign institutional investors to trade in the A share market. By the end of 2007, fifty-two foreign institutional investors had been granted QFII status, and allocated a quota total US $\$ 10$ billion. As documented in Gul, Kim, and Qie (2010), greater levels of foreign holdings and the use of a high-quality auditor results in stock prices that are less synchronized in China. More importantly, the introduction of foreign institutions has had a stabilizing effect on China's A share market, with the effects of feedback trading diminishing in the market, consistent with foreign institutions trading on fundamental strategies and information (Schuppli and Bohl 2010). The evidence suggests that continued relaxation of rules on foreign investment activity and foreign ownership is expected to have a long-run positive effect on corporate transparency in China. ${ }^{11}$

The implementation of various governance-related requirements should also produce similar market pressures. For example, Ferreira and Laux (2007) document how better firm-level corporate governance, as measured by the absence or presence of antitakeover provisions, is associated with

11. Similarly, the creation of the Qualified Domestic Institutional Investor (QDII) program in May 2006, which allows licensed domestic institutional investors to invest in overseas markets, will expose domestic investors to the better levels of transparency that exist on most foreign markets. This exposure to foreign practices may increase the demand for better information in the domestic market. As of the end of 2007, fifteen fund management firms and five securities firms have been granted QDII status. 
greater transparency (as proxied by stock return synchronicity) through its influence on private information collection activities. Thus, the enactment and enforcement of regulations or exchange rules that effectively promote better governance, such as the insider trading restrictions and independent director requirements already in place, should also increase market pressures for greater corporate transparency.

Finally, the elimination of the exchange and regulatory frictions that prevent effective arbitrage activity would increase the expected gains to private information acquisition and dissemination activities. Combined with the strengthening of property rights arising through better enforcement and a strong judicial system, this increase in expected arbitrage profits will create an incentive for informed traders and investors to enter the market, which will improve the efficiency of the price formation process.

\section{Relaxing State Control of Listed Firms}

As shown in our research, one key institutional constraint that leads to the appointment of low-quality auditors is government ownership of listed firms in China. Similarly, state control facilitates propping activities and related political incentives influence the flow of information into prices. As such, any change in the state's role as the principle shareholder for China's listed firms is expected to have an impact on corporate transparency in the long run.

Three recent trends in China are reducing government's influence on the listed firms. First, there has been an increase in the number of privately controlled firms listed in the stock exchanges in China; given that non-statecontrolled firms are more likely to seek a high-quality audit, these listing trends bode favorably for an improvement in corporate transparency in the long run. Second, the government has recently been granted permission to freely transfer their state shares to private investors. These private investors will need to rely upon independent auditors to help them monitor the company, and increase the demand for high-quality external financial reports. Lastly, the increase of foreign ownership through New York, London, and Hong Kong listing of Chinese firms, as well as the creation of the QFII program, will also help reduce the government influence over listed companies in China. The gradual erosion of the government influence and control over China's listed firms is expected to improve the corporate transparency in the long run.

\subsection{Conclusion}

The information environment of China's listed firms is opaque. This chapter has outlined the key institutional arrangements that limit both the demand for and supply of information about China's listed companies. This chapter also raises numerous questions for future research. What are the key 
drivers of observed improvement in China's information environment over the last decade? What are the key reforms and enforcement events in China, and have these activities had the desired effect on the information environment and the development of China's capital markets? Has the arrival of foreign capital and sophisticated investors into the Chinese market improved the information environment? Who is likely to benefit from greater transparency, and how much priority should be given to the further improvement of the information environment? The answers to these fundamental questions, and their implications, will help China continue along its path of long-term economic development.

Fundamentally, any set of actions that shifts the incentives of managers and local politicians to promote transparency is expected to have a profound effect on the information environment of Chinese listed firms. In this regard, China has taken significant steps in the last several years to change these incentives, as outlined in the preceding section. If the ultimate, long-run objective is to align the reporting and disclosure incentives of politicians, executives, and controlling shareholders with transparency, additional legal and market reforms are needed. Our chapter serves as a vital first step in understanding the important economic links between transparency in China's security markets and the country's institutional environment.

\section{References}

Aharony, J., J. Lee, and T. J. Wong. 2000. "Financial Packaging of IPO Firms in China." Journal of Accounting Research 38 (1): 103-26.

Alford, A., J. Jones, R. Leftwich, and M. Zmijewski. 1993. "Relative Informativeness of Accounting Disclosures in Different Countries." Journal of Accounting Research 31 (Supplement): 183-233.

Allen, F., J. Qian, and M. Qian. 2005. "Law, Finance and Economic Growth in China." Journal of Financial Economics 77:57-116.

Allen, W., and H. Shen. 2011. "Assessing China's Top-Down Securities Markets." Working Paper. New York University School of Law. NBER Working Paper no. 16713. Cambridge, MA: National Bureau of Economic Research, January.

Ang, J., and Y. Ma. 1999. "Transparency in Chinese Stocks: A Study of Earnings Forecasts by Professional Analysts." Pacific-Basin Finance Journal 7 (2): 129-55.

Ball, R., S. P. Kothari, and A. Robin. 2000. "The Effect of International Institutional Factors on Properties of Accounting Earnings." Journal of Accounting and Economics 29 (1): 1-51.

Ball, R., A. Robin, and J. Wu. 2001. "Accounting Standards, the Institutional Environment and Issuer Incentives: Effect of Timely Loss Recognition in China." Asia-Pacific Journal of Accounting and Economics 36 (1-3): 235-70.

2003. "Incentives versus Standards: Properties of Accounting Income in Four East Asia Countries." Journal of Accounting and Economics 36 (1-3): 235-70.

Barry, C., and S. Brown. 1985. "Differential Information and Security Market Equilibrium.” Journal of Financial and Quantitative Analysis December:407-22. 
Becker, C., M. DeFond, J. Jiambalvo, and K. R. Subramanyam. 1998. "The Effect of Audit Quality on Earnings Management." Contemporary Accounting Research 15:1-24.

Berkowitz, D., K. Pistor, and J. F. Richard. 2003. "Economic Development, Legality and the Transplant Effect." European Economic Review 47:165-95.

Bhattacharya, U., and H. Daouk. 2002. "The World Price of Insider Trading." The Journal of Finance 57:75-108.

Bhattacharya, U., H. Daouk, and M. Welker. 2003. "The World Price of Opacity." The Accounting Review 78 (3): 641-78.

Botosan, C. 1997. "Disclosure Level and the Cost of Equity Capital." The Accounting Review July:323-49.

Burgstahler, D., and I. Dichev. 1997. "Earnings Management to Avoid Earnings Decreases and Losses." Journal of Accounting and Economics 24 (1): 99-126.

Bushman, R., and J. Piotroski. 2006. "Financial Reporting Incentives for Conservative Accounting: The Influence of Legal and Political Institutions." Journal of Accounting and Economics 42 (1/2): 107-48.

Bushman, R., J. Piotroski, and A. Smith. 2004. "What Determines Corporate Transparency?" Journal of Accounting Research 42 (2): 207-52.

- 2005. "Insider Trading Restrictions and Analysts' Incentives to Follow Firms." The Journal of Finance 60 (1): 35-66.

- 2011. "Capital Allocation and the Timely Accounting Recognition of Losses." Journal of Business, Finance and Accounting 38 (1-2): 1-33.

Chan, L. K. C., N. Jegadeesh, and J. Lakonishok. 1996. "Momentum Strategies." Journal of Finance 51:1681-713.

Chaney, P., M. Faccio, and D. Parsley. 2008. "The Quality of Accounting Information in Politically Connected Firms." Working Paper. Vanderbilt University.

Chen, J., H. Hong, and J. Stein. 2001. "Forecasting Crashes: Trading Volume, Past Returns, and Conditional Skewness in Stock Prices." Journal of Financial Economics 61:345-81.

Chen, K., and J. Wang. 2007. "Accounting-Based Regulation in Emerging Markets: The Case of China's Seasoned-Equity Offerings." The International Journal of Accounting 42:221-36.

Chen, K., and H. Yuan. 2004. "Earnings Management and Resource Allocation: Evidence from China's Accounting-based Regulation of Rights Issues." The Accounting Review 79 (3): 645-65.

Chen, X., C. J. Lee, and J. Li. 2003. "Chinese Tango: Government Assisted Earnings Management." Working Paper. Tsinghua University, Tulane University and Columbia University.

China Securities Regulatory Commission. 2008. Annual Report. Beijing: China Financial and Economic Publishing House.

Choi, J., L. Jin, and H. Yan. 2010. "What Does Stock Ownership Breadth Measure?" NBER Working Paper no. 16591. Cambridge, MA: National Bureau of Economic Research, December.

DeFond, M., M. Hung, and R. Trezevant. 2007. "Investor Protection and the Information Content of Annual Earnings Announcements: International Evidence." Journal of Accounting and Economics 43:37-67.

DeFond, M., T. J. Wong, and S. Li. 2000. "The Impact of Improved Auditor Independence on Audit Market Concentration in China." Journal of Accounting and Economics 28:269-305.

Doidge, C. 2004. "U.S. Cross-listings and the Private Benefits of Control: Evidence from Dual-Class Shares." Journal of Financial Economics 72:519-53.

Doidge, C., G. Karolyi, and R. Stulz. 2004. "Why Are Foreign Firms Listed in the U.S. Worth More?" Journal of Financial Economics 71:205-38. 
Du, F. 2011. "Political Connections and Access to Bond Capital: Reputation or Collusion?" Working Paper. University of Southern California.

Durnev, A., R. Morck, B. Yeung, and P. Zarowin. 2003. "Does Greater Firm-Specific Return Variation Mean More or Less Informed Stock Pricing?" Journal of Accounting Research 41:797-836.

Fama, E., and M. Jensen. 1983. "Agency Problems and Residual Claims." Journal of Law and Economics 26 (2): 327-49.

Fan, J., M. Rui, and M. Zhao. 2008. "Public Governance and Corporate Finance: Evidence from Corruption Cases." Journal of Comparative Economics 36 (3): 343-64.

Fan, J. P. H., and T. J. Wong. 2002. "Corporate Ownership Structure and the Informativeness of Accounting Earnings in East Asia." Journal of Accounting and Economics 33 (3): 401-25.

Fan, J. P. H., T. J. Wong, and T. Zhang. 2007. "Politically Connected CEOs, Corporate Governance and Post-IPO Performance of China's Newly Partially Privatized Firms." Journal of Financial Economics 84:265-90.

Ferreira, M., and P. Laux. 2007. "Corporate Governance, Idiosyncratic Risk and Information Flow." The Journal of Finance 62:951-89.

Francis, J., I. Khurana, and R. Pereira. 2003. "Investor Protection Laws, Accounting and Auditing around the World." Asia-Pacific Journal of Accounting and Economics 10:1-30.

Francis, J., R. LaFond, P. Olsson, and K. Schipper. 2004. "Costs of Equity and Earnings Attributes." The Accounting Review 79 (4): 967-1010.

Gelos, R., and S. Wei. 2004. "Transparency and International Investor Behavior." Journal of Finance 42:721-41.

Guedhami, O., and J. Pittman. 2006. "Ownership Concentration in Privatized Firms: The Role of Disclosure Standards, Auditor Choice, and Auditing Infrastructure." Journal of Accounting Research 44 (x): 889-929.

Guedhami, O., J. Pittman, and W. Saffar. 2009. "Auditor Choice in Privatized Firms: Empirical Evidence on the Role of State and Foreign Owners." Journal of Accounting and Economics 48 (x): 151-71.

Gul, F. 2006. "Auditors' Response to Political Connections and Cronyism in Malaysia." Journal of Accounting Research 44 (5): 931-63.

Gul, F., J. Kim, and A. Qiu. 2010. "Ownership Concentration, Foreign Shareholdings, Audit Quality, and Stock Price Synchronicity: Evidence from China.” Journal of Financial Economics 25 (3): 425-42.

He, Z., and D. Su. 2009. "Price Manipulation and Industry Momentum: Evidence from the Chinese Stock Market.” Working Paper. Jinan University, March.

Hung, M., T. J. Wong, and F. Zhang. 2011. "The Value of Relationship-Based and Market-Based Contracting: Evidence from Corporate Scandals in China."Working Paper. The Chinese University of Hong Kong.

Jegadeesh, N., and S. Titman. 1993. "Returns to Buying Winners and Selling Losers: Implications for Stock Market Efficiency.” Journal of Finance 48:65-91.

Jensen, M., and W. Meckling. 1976. "Theory of the Firm: Managerial Behavior, Agency Costs and Ownership Structure.” Journal of Financial Economics 3:305-60.

Jian, M., and T. J. Wong. 2010. "Propping and Tunneling through Related Party Transactions." Review of Accounting Studies 15:70-105.

Jiang, G., C. M. C. Lee, and H. Yue. 2010. "Tunneling in China: The Surprising Pervasive Use of Corporate Loans to Extract Funds from Chinese Listed Firms." Journal of Financial Economics 98 (1): 1-20.

Jin, L., and S. Myers. 2006. "R2 around the World: New Theory and New Tests." Journal of Financial Economics 79:257-92. 
Kang, J., M.-H. Liu, and S. Ni. 2002. "Contrarian and Momentum Strategies in the China Stock Market: 1993-2000.” Pacific-Basin Finance Journal 10:243-65.

Kao, J. L., D. Wu, and Z. Yang. 2009. "Regulations, Earnings Management, and Post-IPO Performance: The Chinese Evidence." Journal of Banking and Finance 33 (1): 63-76.

Karpoff, J., D. S. Lee, M. Arvind, and G. Martin. 2004. "Penalizing Corporate Misconduct: Empirical Evidence." Working Paper. University of Washington and University of Texas A\&M.

Karpoff, J., D. S. Lee, and G. Martin. 2008a. "The Consequences to Managers for Financial Misrepresentation.” Journal of Financial Economics 88:193-215.

_. 2008b. "The Cost to Firms Who Are Cooking the Books." Journal of Financial and Quantitative Analysis 43 (3): 581-612.

Khwaja, A., and A. Mian. 2005. "Unchecked Intermediaries: Price Manipulation in an Emerging Stock Market." Journal of Financial Economics 78:203-41.

Kling, G., and L. Gao. 2008. "Chinese Institutional Investors' Sentiment." Journal of International Financial Markets, Institutions and Money 18:374-87.

Lang, M., and R. Lundholm. 1996. "Corporate Disclosure Policy and Analyst Behavior." The Accounting Review October:467-92.

Leuz, C., D. Nanda, and P. Wysocki. 2003. "Earnings Management and Institutional Factors: An International Comparison." Journal of Financial Economics 69 (3): $505-27$.

Leuz, C., and F. Oberholzer-Gee. 2006. "Political Relations, Global Financing, and Corporate Transparency: Evidence from Indonesia." Journal of Financial Economics 81 (2): 411-39.

Liu, Q., and Z. Lu. 2007. "Corporate Governance and Earnings Management in Chinese Listed Companies: A Tunneling Perspective." Journal of Corporate Finance 13 (5): 881-906.

Liu, Q. 2006. “Corporate Governance in China: Current Practices, Economic Effects and Institutional Determinants." CESifo Economic Studies 52 (2): 415-53.

Mei, J., J. Scheinkman, and W. Xiong. 2005. "Speculative Trading and Stock Prices: Evidence from China's A-B Share Premia.” NBER Working Paper no. 11362. Cambridge, MA: National Bureau of Economic Research, May.

Merton, R. 1987. "A Simple Model of Capital Market Equilibrium with Incomplete Information." The Journal of Finance July:483-510.

Morck, R., B. Yeung, and W. Yu. 2000. "The Information Content of Stock Markets: Why Do Emerging Markets Have Synchronous Stock Price Movements?” Journal of Financial Economics 58:215-60.

Naughton, T., C. Truong, and M. Veeraraghavan. 2008. "Momentum Strategies and Stock Returns: Chinese Evidence.” Pacific-Basin Finance Journal 16:476-92.

Piotroski, J., T. J. Wong, and T. Zhang. 2011. "Political Incentives to Suppress Negative Financial Information: Evidence from Chinese Listed Firms." Working Paper. Stanford University and the Chinese University of Hong Kong.

Qian, Y., and B. Weingast. 1997. "Federalism as a Commitment to Preserving Market Incentives." Journal of Economic Perspectives 11:83-92.

Rajan, R., and L. Zingales. 2003. "The Great Reversals: The Politics of Financial Development in the 20th Century." Journal of Financial Economics 69:5-50.

Roll, R. 1988. "R²." Journal of Finance 43:541-66.

Schuppli, M., and M. Bohl. 2010. "Do Foreign Institutional Investors Destabilize China's A-share Market? Journal of International Financial Markets, Institutions and Money 20:36-50.

Stulz, R. 1999. "Globalization, Corporate Finance, and the Cost of Capital." Journal of Applied Corporate Finance 12:8-25. 
Tan, L., T. Chiang, J. Mason, and E. Nelling. 2008. "Herding Behavior in Chinese Stock Markets: An Examination of A and B Shares." Pacific-Basic Finance Journal 16:61-77.

Tang, Y. W. 1999. "Issues in the Development of the Accounting Profession in China." China Accounting and Finance Review 1:21-36.

Teoh, S. H., and T. J. Wong. 1993. "Perceived Auditor Quality and the Earnings Response Coefficient." The Accounting Review 68:346-67.

Wang, Q., T. J. Wong, and L. Xia. 2008. "State Ownership, Institutional Environment, and Auditor Choice: Evidence from China." Journal of Accounting and Economics 46 (1): 112-34.

Watts, R. 2006. "What Has the Invisible Hand Achieved?" Working Paper. Massachusetts Institute of Technology.

Watts, R. L., and J. L. Zimmerman. 1986. Positive Accounting Theory. Englewood Cliffs, NJ: Prentice-Hall.

World Economic Forum. 2011. Global Competitiveness Report, edited by Klaus Schwab. Geneva: World Economic Forum.

Yang, L., Q. Tang, A. Kilgore, and J. Hong. 2001. "Auditor-Government Associations and Auditor Independence in China." British Accounting Review 33:175-89.

Yu, Q., B. Du, and Q. Sun. 2006. "Earnings Management at Rights Issuance Thresholds-Evidence from China." Journal of Banking and Finance 30 (12): 3453-68.

Zhong, H. 1998. "Analysis of the Answers to Survey Questions by Chinese CPAs." CPA News 1:59-64.

\section{Comment Li Jin}

Joe Piotroski and T. J. Wong study the financial reporting practices and information environment of Chinese listed firms. The chapter follows Bushman, Piotroski, and Smith (2004) to define corporate transparency as the widespread availability of firm-specific information to market participants outside the publicly-listed firm, and categorize country, regional, and firmlevel information mechanisms into three broad headings: (1) the corporate reporting regime, which includes the quality of the firm's financial reports and the underlying audit function; (2) the intensity of private information acquisition activities, which includes the depth and breadth of analyst and institutional investor activity; and (3) the strength of dissemination mechanisms, including the role of media and freedom of the press.

Judged by a variety of standards, corporate transparency in China is not satisfactory. At the stock level, Chinese stocks have high synchronicity, meaning less meaningful firm-specific information is incorporated in the stock prices. There is also high crash likelihood, suggesting that bad news often accumulates in the firm for lack of better disclosure, and only later comes out in batches. Survey evidence indicates that while the over-

Li Jin is associate professor of business administration at Harvard Business School.

For acknowledgments, sources of research support, and disclosure of the author's material financial relationships, if any, please see http://www.nber.org/chapters/c12465.ack. 